\title{
Do Greater Shareholder Voting Rights Reduce Expropriation? Evidence from Related Party Transactions
}

\author{
Nan Li
}

Submitted in partial fulfillment of the requirements for the degree of Doctor of Philosophy under the Executive Committee of the Graduate School of Arts and Sciences

\section{COLUMBIA UNIVERSITY}

2018 
(C) 2018

Nan Li

All Rights Reserved 


\section{ABSTRACT \\ Do Greater Shareholder Voting Rights Reduce Expropriation? Evidence from Related Party Transactions}

\section{Nan Li}

In the presence of business groups, the expropriation through related party transactions (RPTs) is common and costly to minority shareholders. At the same time, it is well recognized that RPTs can help firms overcome market shortcomings. Using the setting of India's RPT voting rule, I find that a mandatory and binding shareholder voting mechanism helps filter out expropriation. Minority shareholders actively raise their voice against RPT resolutions, resulting in substantial shareholder dissent. My difference-in-difference analysis reveals that shareholder voting has a significant deterrence effect on RPT volume, especially on financial RPTs. I also find that stock prices react positively to news signaling the passage of the voting rule, and that the association between firm profitability and RPT increases following rule's adoption, suggesting that rule has a positive effect on shareholder value. Lastly, I show that mandatory RPT voting makes Indian firms more attractive to foreign institutional investors. 


\section{TABLE OF CONTENTS}

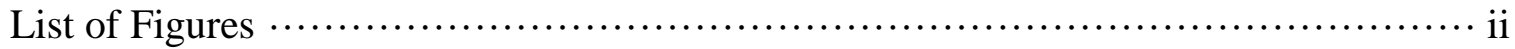

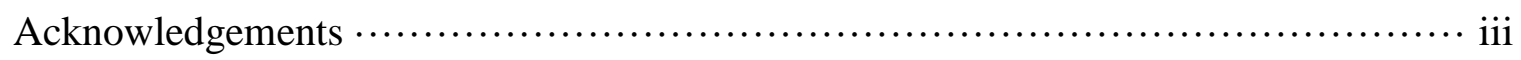

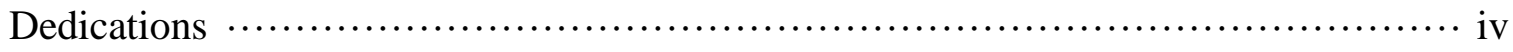

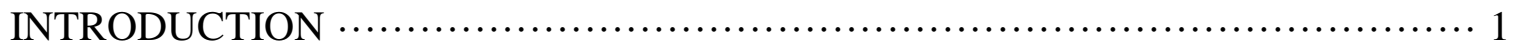

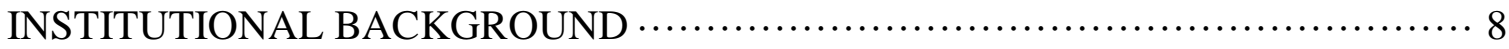

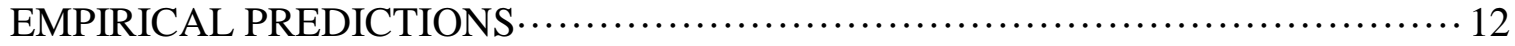

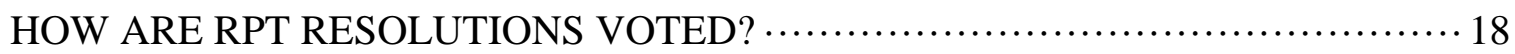

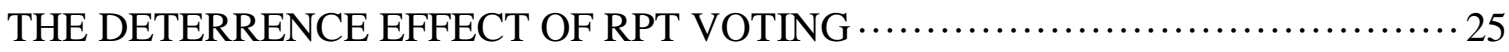

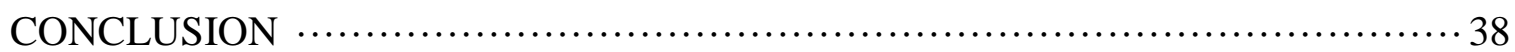

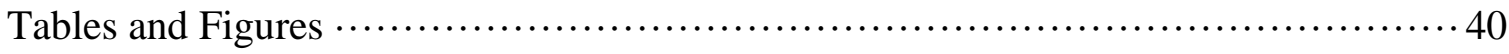

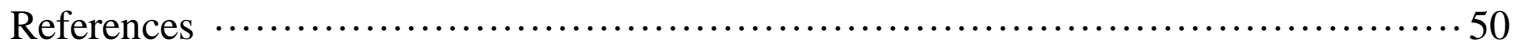

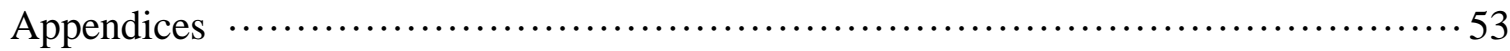




\section{List of Figures}

Figure 1: Differential Trends of RPTs around Voting Rule $\ldots \ldots \ldots \ldots \ldots \ldots \ldots \ldots \ldots \ldots \ldots \ldots$ 


\section{Acknowledgements}

I am grateful for the support of my dissertation committee, Fabrizio Ferri (co-sponsor), Shiva Rajgopal (co- sponsor), Tim Baldenius (chair), Trevor Harris, and Wei Jiang. I benefited from the comments of Bernard Black, Jonathan Glover, Robert Stoumbos and workshop participants at Columbia University, University of Colorado-Boulder, University of Illinois-Chicago, University of Minnesota, University of Texas-Austin and Ohio State University. I am thankful for financial support from the W. Edwards Deming Center and the Jerome A. Chazen Institute. 
This work is dedicated to my parents 


\section{Introduction}

I examine whether the adoption of mandatory shareholder voting on related party transactions (RPT) reduces the expropriation of minority shareholders. In countries where companies' ownership structure is highly concentrated, a central agency problem is how to protect minority shareholders from expropriation attempts by controlling shareholders (La Porta, Lopez-de Silanes, and Shleifer (1999)). Minority shareholders can be particularly vulnerable in the presence of business groups, a common organizational form where multiple entities are controlled by a single individual or family. The controlling shareholders have the incentive to transfer resources across group firms through RPTs, ultimately to their own pockets. Such transfer, also called "tunneling", can take many forms, such as financial assistance, purchasing or selling of assets, and transfer pricing. If pervasive, the fear of expropriation can dampen corporate valuation, impede market development and even aggravate financial crises (La Porta, Lopez-de Silanes, Shleifer, and Vishny (2002)).

Indeed, previous studies find that expropriation through RPTs is common and costly to minority shareholders (Bertrand, Mehta, and Mullainathan (2002), Cheung, Rau, and Stouraitis (2006), Kohlbeck and Mayhew (2010)). At the same time, though, it is well recognized that when certain market mechanisms are not well developed, within-group transactions can serve as alternative means to overcome these market shortcomings (Khanna and Palepu (2000)). Consider the example of integrating a supplier and a customer into the same group. Such integration can help secure the supply chain when contracting is costly. Because RPTs serve important business and financing purposes whilst also providing opportunities for a substantial transfer of wealth from minority to controlling shareholders, they present a significant challenge for policy makers (OECD (2012)). Outright prohibition of RPTs would be too costly, and identifying mechanisms that preserve the benefits of RPTs while limiting their abuses has proven to be difficult.

In this paper, I investigate whether a mandatory and binding shareholder vote on RPTs reduces the expropriation of minority shareholders, and, whether its net effect on shareholder 
value is positive. A mandatory and binding voting mechanism may affect RPTs in two ways. First, it serves as an ex-post monitoring device that prevents transactions that shareholders collectively view as detrimental to shareholder value. Second, a large number of votes against a RPT resolution, even if not sufficient to outright block the RPT, can impose reputation costs on controlling shareholders or board members, who may decide not to proceed with the transaction or revise it based on the input received via the shareholder vote. ${ }^{1}$ The effect of shareholder voting does not only manifest in the vote cast. In anticipation of the potential veto and reputation cost, controlling shareholders may be deterred from proposing transactions that would be perceived to hurt minority shareholders.

By leaving the trigger to the collective wisdom of voting shareholders, the voting mechanism can offer the flexibility to curb the negative effects of RPTs without disrupting their value-creating potential. In principle, informed shareholders will only vote against transactions deemed detrimental to shareholder value and support those arranged to facilitate business strategies. In practice, however, shareholder voting may fail to fulfill such governance role for a number of reasons. First, minority shareholders may choose not to actively exercise their voting rights because they believe that their individual vote will not affect the voting outcome ("shareholder passivity", Black (1990)). Overcoming this classic collective action problem requires implicit or explicit coordination, such as collective shareholder organizations or proxy advisors, as well as a voting rule that allows minority shareholders to have a reasonable chance to win a majority vote. Second, lack of information (e.g., opaque disclosures on RPTs) or lack of shareholders' sophistication may prevent shareholder votes from successfully separating RPTs aimed at expropriation from those with a legitimate business purpose. If so, shareholder voting may end up targeting value-creating transactions. ${ }^{2}$

\footnotetext{
${ }^{1}$ The costs of receiving strong shareholder dissent can include deteriorating trust to the controlling shareholders, reputation and career concerns of board members, litigation risk, the risk of regulatory scrutiny and intervention. I use the phrase "reputation cost" as a shorthand for the sum of these costs.

${ }^{2}$ This problem is exacerbated by the possibility that controlling shareholders design RPTs which at the same time serve a valid business purpose and allow for some expropriation, leaving minority shareholders with the choice between approving the proposed RPT in spite of expropriation or blocking it at the risk of disrupting business operations. This is akin to the problem of "bundling", when a management proposal
} 
Third, not all minority shareholders have the incentive to cast an "against" vote, because doing so may negatively affect their relationship with management or controlling shareholders. Finally, the effectiveness of the shareholder voting threat also depends on the potential reputation costs associated with a strong display of shareholder opposition. The presence and extent of these costs largely depend on the specific features of the institutional setting and information environment. Thus, whether and how greater voting rights affect RPTs and shareholder value remains an empirical question.

To shed light on this question, I examine the adoption of a mandatory voting rule on RPTs in India. India's corporate sector is dominated by large business groups. A single individual (called promoter) or family usually maintains the de facto control of all group firms. Despite the common law heritage, the concentrated control rights, combined with corruption and lax law enforcement, have made RPT abuse a major concern (Bertrand et al. (2002)). In 2009, the concern escalated following the breakout of the Satyam scandal, which was at first exposed by suspicious RPTs. In the subsequent revision of corporate law, known as the Companies Act, 2013, the Indian legislators included a provision mandating that listed companies seek shareholder approval for material related party transactions before they take place. The Securities and Exchange Board of India (SEBI) also adopted a similar rule in the revised listing agreement. Under the SEBI's rule, if a firm's expected sum of transactions with an individual party in a financial year exceeds $10 \%$ of the firm's most recent total revenue, the transactions with that party are classified as material. Importantly, the rule only allows "disinterested" shareholders to vote, meaning that shareholders classified as connected to the related party (typically the case for promoters) are not eligible to vote on RPT resolutions. Hence, material RPTs must be approved by shareholders who have no connection to the related parties.

As a first step in my empirical analysis, I use voting data to provide descriptive evidence bundles together both value-destroying and value-creating value-destroying items (Cox, Ferri, Honigsberg, and Thomas (2016)). 
on how shareholders vote on RPT resolutions. In a sample of 348 RPT resolutions in 2014 and 2015 (the first two years after the RPT voting rule's implementation), I find that 9.77\% of the RPT resolutions receive more than 25\% "against" votes of the votes cast from eligible shareholders, significantly higher than the corresponding frequency of non-RPT resolutions $(0.56 \%)$ at the same firm. Notably, $7.78 \%$ for RPT resolutions fail to pass ${ }^{3}$, suggesting that the threat of a failed vote is real. ${ }^{4}$ I then use regressions to explore the determinants of RPT resolutions' voting outcomes in the cross section. I find that the firm's total RPT volume is positively associated with the extent of shareholder dissent, suggesting shareholders are more likely to vote against RPT resolutions proposed by firms that engage in a high volume of RPTs. However, after decomposing the total RPT volume into operating and financing components, I show that only financing RPT strongly predicts shareholder dissent. Collectively, the descriptive evidence shows that in India: (i) shareholders are significantly more likely to vote against RPTs than other proposals being voted at the same firm; (ii) some RPT proposals are voted down, suggesting that shareholder voting can act as ex post monitoring device and may also serve as an ex ante threat; (iii) shareholders' votes depend on the firm-level volume and type of RPTs, indicating at least the attempt to discern among different types of RPTs.

In the second step, I tackle my research question more broadly by examining the voting rule's overall deterrence effect ${ }^{5}$ on the use of RPTs, and especially those RPTs more likely to result in expropriation of minority shareholders. To do so, I employ a difference-in-differences (DID) design comparing the change in volume and type of RPTs around the treatment event

\footnotetext{
${ }^{3}$ The requisite majority for RPT resolutions was initially $75 \%$ and was revised down to $50 \%$. For other resolutions the threshold is typically $50 \%$.

${ }^{4}$ As a benchmark, Ertimur, Ferri, and Oesch (2013) find that only 1.9\% of mandatory (non-binding) "say-on-pay" proposals in the U.S. fail to pass the $50 \%$ threshold, suggesting the dissent received by RPT resolutions in India is high even when compared to a country and a topic (the U.S. "say-on-pay") characterized by substantial activism via voting. Admittedly, the comparison is imperfect because executives can vote on "say on pay" in the U.S., but exclusion of those votes would have only a minimal effect on the frequency of failed "say on pay" votes.

${ }^{5}$ In this paper, I use a broad definition for deterrence, which includes both ex ante threat and realized shareholder dissent.
} 
between treated and control groups. To construct a control sample, I exploit the fact that shareholder approval is only mandatory for "material" transactions. I classify firms into the treated group and control group based on whether their RPTs prior to the voting rule met the materiality criteria. The underlying logic is that firms who in the past had RPTs that would be labelled as "material" under the new rule are more likely to be affected by the rule than firms who did not. The DID multivariate estimation shows that, controlling for observable characteristics, the treated firms on average experience a 0.079 reduction in Total RPT (i.e. the ratio of total RPT volume to lagged total assets) relative to the control firms, representing a $14 \%$ percentage decrease from their pre-treatment level of 0.56 .

I then investigate whether the observed effect varies by the types of RPTs. Related literature (e.g., Cheung et al. (2006), Jiang, Lee, and Yue (2010)) suggests that financing RPTs can be particularly concerning due to their ability to transfer large sums of money outside firms' ordinary courses of business. The previous analysis of voting outcomes also indicates that shareholders express greater concerns about this type of transactions. Thus, I predict that financing RPTs are more prone to being used for expropriation than operating transactions, and have a larger decrease following the voting rule's adoption. After decomposing Total RPT into Financing RPT and Operating RPT, the DID estimation shows that Financing RPT decreases by 0.05 for the treated group relative to the control group, a $19 \%$ drop from the pre-treatment level of 0.26 . The estimated effect on Operating RPT is modest, at 0.02 and not significant at conventional levels. Overall, these results suggest that the voting rule's deterrence effect is not only substantial, but also varies by the nature of transactions.

Such deterrence effect is not necessarily value-creating. Managers may be reluctant to discover or propose complex RPTs with a valid business purpose if they anticipate that minority shareholders may not understand the transactions and vote against them. In the next step, I study the value implication of the RPT voting rule, using two approaches. First, I examine how stock prices react to news related to the passage of the RPT voting rule. Overall, the market reacts positively to the key legislative milestones that signal a higher 
likelihood of the rule's passage, implying that investors expect the voting rule to enhance shareholder value. Investors' ex ante expectations about the effect of regulation, though, do not necessarily materialize. To corroborate the event study with ex post evidence of the effect on firm value, I use the DID design to investigate changes in the association between RPT level and firm profitability around the voting rule's actual implementation. If the voting rules help filter out expropriation from value-creating RPTs, the association should become more positive (or less negative) after the new rules (Black, Kim, Jang, and Park (2015)). Indeed, I find that treated firms experience an increase in the association between RPT level and profitability relative to control firms.

Lastly, motivated by the finding that good corporate governance attracts institutional investors (Ferreira and Matos (2008), Leuz, Lins, and Warnock (2008)), I test whether mandatory voting on RPT leads to higher institutional holdings. I find that treated firms experience a significant increase in institutional ownership relative to control firms following the voting rule's adoption. The increase is primarily driven by foreign institutional holdings, which increase by $0.8 \%$ for the treated firms compared to the control firms, a $21 \%$ percentage change over the pre-treatment level (3.9\%). This evidence is consistent with the notion that foreign investors can be particularly sensitive to formal governance mechanisms such as voting rights (Kho, Stulz, and Warnock (2009)).

This study makes several contributions. First, it informs the research and policy debate on the regulations of related party transactions. The potential abuses of RPTs are viewed as an important policy issue around the world (OECD (2012)). Historically, in most regimes the approval of RPTs is primarily delegated to independent directors. However, scandals like the Satyam case suggest that, even after regulatory efforts to boost board independence globally, director approval alone may not be sufficient to protect minority shareholders from expropriation. Another approach has been to require greater disclosures of RPTs (e.g., IAS 24). Yet, without the power to act on the information, disclosures alone may not be sufficient to curb abusive RPTs (OECD (2012)). Mandatory voting enables shareholders to act on 
the information from public disclosure and incentivizes them to demand more transparent disclosures in the first place. It may also provide independent directors with the "backbone" to oppose questionable transactions and amplify their reputation concerns. In other words, mandatory voting can complement the effect of board independence and disclosures. Relatedly, my paper extends the literature examining investor protection, expropriation and financial development (Johnson, Boone, Breach, and Friedman (2000), La Porta et al. (2002), Djankov, La Porta, Lopez-de Silanes, and Shleifer (2008)). While this literature documents that stronger investor protection and better corporate governance are associated with lower levels of expropriation in general, less is known about the exact mechanisms that can reduce expropriation. My evidence echoes Djankov et al. (2008)'s suggestion that, among various regulatory option to curb the self-dealing of controlling shareholders, mandatory shareholder approval (combined with strong disclosures) can have a first-order impact.

Second, this study contributes to the literature on business groups. Many studies document that group structure adds value to firms by providing alternatives to overcome underdeveloped institutions (e.g., Khanna and Palepu (2000), Gopalan, Nanda, and Seru (2007)). At the same time, a wealth of anecdotes and research also suggest that group transactions are sometimes abused by the controlling shareholders to seek rent from the minority shareholders (e.g., Bae, Kang, and Kim (2002), Jiang et al. (2010)). As Khanna and Yafeh (2007) summarize, due to the multifaceted roles business groups can play, one should not one-sidedly characterize them as either paragons or parasites. My study suggests that, by filtering out expropriation from the transactions that serve business strategies, shareholder voting can be a particularly useful mechanism when both elements are present.

Third, I contribute to the nascent literature of shareholder activism in emerging markets. A sizable literature finds that shareholder voting affects corporate governance in developed countries such as the U.S. and the U.K. (e.g., Cuñat, Gine, and Guadalupe (2012), Ferri and Maber (2013)). As Iliev, Lins, Miller, and Roth (2015) emphasize, due to the vast institutional differences, our understanding of shareholder voting in developed markets cannot be 
easily applied to the rest of the world. For example, firms outside the U.S. and U.K. have much more concentrated ownership (La Porta et al. (1999)). If a controlling shareholder controls most of the voting shares, the voting mechanism becomes merely symbolic. In this paper, I utilize a unique empirical setting where the controlling shareholders are excluded from voting. My evidence shows that a "majority-of-minority" voting system allows shareholder voting to be a credible threat and results in lower expropriation. This finding corroborates the results of Fried, Kamar, and Yafeh (2018), who show that Israel's majority-of-minority voting regulation on executive pay curbs the compensation of controlling executives.

Lastly, I contribute to the literature on relationship between corporate governance and institutional holdings (Ferreira and Matos (2008), Aggarwal, Erel, Ferreira, and Matos (2011)). Recent papers provide causal evidence that institutional investors promote good governance (Boone and White (2015), Appel, Gormley, and Keim (2016)). My evidence is consistent with the idea that to attract institutional investors who can act as external monitors, especially foreign institutions, policy makers need to provide robust investor protection (Leuz et al. (2008), Kho et al. (2009)). I show that greater shareholder voting rights that empower shareholders to tackle a major expropriation concern attract foreign institutional investors.

\section{Institutional Background}

The corporate sector in India is characterized by concentrated ownership and the prevalence of business groups. In a company, a person (or entity) who controls the firm overall is legally defined as a promoter. ${ }^{6}$ In practice, a promoter is usually the founder of a company or a member of the founder's family. Within a business group, different firms can have different promoters. However, an individual (or family) usually maintains the de facto control of all group firms, even firms where her equity holding is relatively low. The disparity between cash flow rights and control rights enables controlling shareholders to extract private bene-

\footnotetext{
${ }^{6} \mathrm{~A}$ company can have multiple promoters if the control is shared. In addition, persons or entities related to the promotes through ownership or family relationship are classified as a part of the "promoter group".
} 
fits by transferring resources between firms, ultimately to their own pockets. ${ }^{7}$ This practice, widely known as tunneling, often takes the form of related party transactions (RPTs), such as transfer pricing, inter-corporate loans and buying/selling assets (Bertrand et al. (2002)).

To protect minority shareholders from abusive RPT, the Government of India regulate RPT through both board oversight and public disclosure. Historically, the regulation of RPT has been governed by Clause 49 of the Listing Agreement and accounting standard AS-18. Firstly enacted in 2001, Clause 49 is a corporate governance reform similar in spirit to the Sarbanes-Oxley in the U.S. Clause 49 mandates listed firms to set up auditing committees where at least two thirds of the members are independent directors. Managers are required to disclosure details of RPTs to the auditing committees, who are in charge of reviewing the transactions . AS-18 regulates the public disclosure of RPTs with specific definitions and rules. Under AS-18, listed firms need to disclose details such as the nature of relationship and the amount for each type of transactions with each related party in the footnote of financial statements. ${ }^{8}$

These regulatory efforts, however, have not been sufficient in deterring controlling shareholders from extracting private benefits through RPTs, as exemplified by the Satyam scandal. Satyam Computers was an Indian technology company whose ADR was listed in NYSE. In 2008, the then controlling shareholder of Satyam Computers, Ramalinga Raju, proposed to acquire two real estate companies (Maytas Infrastructure Ltd. and Maytas Properties Ltd.). At that time, the Ramalinga Raju group held 36.6\% of Maytas Infrastructure, an undisclosed

\footnotetext{
${ }^{7}$ Besides directly consuming firm resources, controlling shareholders may realize their private benefits in other ways such as empire building. Another way to abuse RPTs is using them to manipulate accounting numbers (e.g., Jian and Wong (2010), Kohlbeck and Mayhew (2017)). Such manipulation may also be related to more subtle ways of self-dealing (e.g., misleading investors for higher managerial compensations or insider trading opportunities).

${ }^{8} \mathrm{As}$ a benchmark, US firms are required to describe the nature and amount of RPTs in the footnotes to the 10-K filing (per SFAS 57 of U.S. GAAP). In 2014, PCAOB adopted Auditing Standard No. 18 to strengthen the audit procedures for RPTs. Also, the SEC mandates RPT disclosures in proxy filings (the 2006 SEC disclosures call for greater disclosures about the RPT approval process). See Ryngaert and Thomas (2012) and $\mathrm{Lu}$ (2017) for a discussion of the SEC disclosure rule. IFRS also mandate the disclosure of RPT in financial statements, as outlined in IAS 24. For an overview of how U.S. institutions deal with "tunneling" in a broader sense, see Atanasov, Black, and Ciccotello (2011).
} 
stake in Maytas Properties, and only 8.6\% of Satyam Computers. The transactions, expected to transfer USD 1.6 billion from Satyam Computers to the two real estate companies, were approved by the Satyam's independent directors. The investors, however, seriously doubted the motivation behind the acquisitions, sending the price of Satyam's ADR down by 55\% on the announcement day, forcing the deal to a halt. Subsequent investigations revealed that Satyam had for many years engaged in accounting fraud that fabricated over USD 1 billion cash balance (which eventually led to the prosecution and conviction of Ramalinga Raju and a wave of resignation from Satyam directors).

Following the Satyam scandal, the investor communities in India and around the world (e.g., CFA Institute (2009), OECD (2009)) voiced their concerns with abusive RPTs, inadequate board oversight, and more generally the limited accountability of controlling shareholders. In response to these concerns, the legislators in India included updated corporate governance provisions in the ongoing revision of the company law, known as the Companies Act 2013. With a broad scope, the 2013 Act touches areas such as shareholder voting, director compensation, corporate social responsibility and board diversity. ${ }^{9}$

Sections 188 of the 2013 Act requires material related party transactions to be approved by minority shareholders (after being approved by the board). The Security and Exchange Board of India (SEBI) followed up to include a similar shareholder approval provision in the revised Clause 49 of the listing agreement ${ }^{10}$. Under the SEBI's rule, if a firm's expected total transaction amount with a particular related party in a financial year exceeds $10 \%$ of the firm's most recent annual revenue, all the transactions with that party must have a priori shareholder approval. The minimum approval threshold was initially set at $75 \%$ for votes

\footnotetext{
${ }^{9}$ In Section 5.1, I discuss in detail other corporate governance provisions of the 2013 Act and how I control for their potential confounding effects.

${ }^{10}$ Both the 2013 Act and the SEBI's rule mandate shareholder approval for material RPTs, but the SEBI rule is considered more stringent in several aspects. First, the SEBI rule uses a broader definition of related party and related party transactions. Second, the 2013 Act exempt transactions under "ordinary course of business" or "arms-length basis", whereas the SEBI rule does not make the exceptions. Third, the two rules differ in the definition of material transactions, where the SEBI's threshold is tighter in general. Therefore in this paper I used SEBI's materiality threshold for the empirical analysis. For simplicity, hereafter I refer the provision in the 2013 Act and SEBI rule collectively as "the voting rule".
} 
of the eligible votes cast and was revised to $50 \%$ one year after the rule came into effect. Furthermore, only "disinterested" shareholders are eligible to vote on RPT resolutions, which means promoters usually cannot vote as they are often connected to the related parties. ${ }^{11}$ Due to the concentrated ownership of Indian companies, the "majority-of-minority" feature of the voting rule significantly amplifies the voting power of minority shareholders. ${ }^{12}$

The Indian setting is suitable for answering my research questions for several reasons. First, the dominance of business groups with concentrated control rights gives promoters strong incentive to expropriate minority shareholders through RPTs. At the same time, the potential loss to minority shareholders is large enough to give them incentives to overcome their passivity and actively exercise their voting powers. Second, the Indian RPT voting rule is mandatory (thus mitigating selection bias) and the voting outcome is legally binding, which implies that minority shareholders do not rely on the reputation impact alone to stop RPTs, as would be the case with advisory votes. Third, the Indian RPT voting rule explicitly excludes controlling shareholders connected to the related parties from voting, making the rule particularly protective to minority shareholders. This feature also provides shareholders with stronger incentives to gather information, coordinate and cast an informed vote. Finally, the focus on material party transactions allows me to identify a suitable control sample in my research design, as discussed in detail in Section 5.

\footnotetext{
${ }^{11}$ When the rule first came into effect, the general interpretation was that all promoters have to abstain from voting. The lawmakers later clarified that promoters proven to have no connection with the related parties can vote. However, such cases are uncommon. By the same logic, non-promoters shareholders who are connected to the related parties are not allowed to vote. Practically, the task of verifying voting eligibility belongs to the scrutinizer, an outside party appointed by the board to monitor the voting process and validate the votes. Public accountants and professional company secretaries are frequently used as scrutinizers.

${ }^{12}$ See Enriques (2015) for a discussion of the "majority-of-minority" voting rule proposed by the European Commission. Another example of a similar voting rule is the Australian "say on pay" (SOP) regime, where directors and managers are not eligible to vote on SOP resolutions (Bugeja, da Silva Rosa, Shan, Walter, and Yermack (2016)).
} 


\section{Empirical Predictions}

I develop the predictions tested in this paper based on the frameworks in Johnson et al. (2000) and La Porta et al. (2002). In these models, a controlling shareholder can extract

private benefits by stealing a fraction of firm profits (or investment). The stealing, however, is subject to a private cost which is a function of the amount stolen and the strength of investor protection. In equilibrium, the controlling shareholder chooses the level of expropriation that equates the marginal private benefit to the marginal cost.

Although the models do not feature shareholder voting, a voting rule can enter the framework in two ways. First, a voting rule can serve as an ex-post monitoring mechanism that can probabilistically undo the controlling shareholders' stealing. The voting outcome should be determined by the percentage of against votes, which in turn can be thought as a noisy measure of the stealing level. If the realized percentage of against votes exceeds the requisite majority and the voting outcome is binding, the stealing is completely undone. Second, the public disclosure of the voting outcome can impose a reputation cost to the controlling shareholder. If a firm discloses a high level of against votes, even if not sufficient to block the transaction, shareholders may react negatively by selling shares or applying stronger scrutiny in the future. Similarly, strong shareholder dissent can push independent directors (concerned with their reputation) and regulators to apply more stringent oversight that leads to a higher cost of future expropriation. The reputation costs should also increase with the percentage of against votes.

Under the shareholder voting regime, a controlling shareholder who proposes a positive amount of stealing would face a probability of veto and a reputation cost. In response to the threat of veto and reputation costs, the controlling shareholders would not propose RPTs that are likely to attract strong a high level of against votes. Taken together, the RPT voting rule should reduce the level of RPT-related expropriation through both realized veto and deterrence.

To illustrate the framework, first consider the baseline model of La Porta et al. (2002). 
A controlling shareholder with cash flow rights $\alpha$ can choose to expropriate a fraction $(s)$ of the firm's investment subject to a private cost $c(k, s)$. If the amount of investment and the gross return are both normalized to 1, the controlling shareholder's payoff is

$$
\alpha(1-s)+s-c(k, s)
$$

where the first term is his after-theft dividends, the second term is the private benefit of expropriation and the third term is the private cost, an increasing function of $s$ and the general investor protection $k{ }^{13}$ This is the same expression as equation (2) of La Porta et al. (2002). Assuming a quadratic cost function $c(k, s)=\frac{1}{2} k s^{2}, k>0$, the first order condition gives the following equilibrium level of expropriation

$$
s^{*}=\frac{1-\alpha}{k} .
$$

Now I modify the set up by introducing shareholder voting when the expropriation is proposed but not yet executed. Let $p(v, s)$ denote the probability of vetoing the transaction, where $s$ still represents the expropriation level and $v$ captures the strength of the voting rule and shareholder participation. Assume $p$ increases monotonically with $s$ (i.e. more serve expropriations are more likely to be blocked $).{ }^{14}$ Let $r(d, p)$ be the expected reputation cost from the public disclosure of the voting outcome, which monotonically increases with $p . d$ is a parameter that captures the sensitivity of reputation cost to the voting outcome, which can be thought as public awareness or media coverage. Under the shareholder voting regime, the expected payoff to the controlling shareholder is given by

$$
\alpha p(v, s)+(1-p(v, s))(\alpha(1-s)+s)-c(k, s)-r(d, p),
$$

\footnotetext{
${ }^{13} \mathrm{La}$ Porta et al. (2002) call $c(k, s)$ the cost of-theft function, which is the resource the controlling shareholder has to waste in order to steal $s$. One such example is bribing the regulator.

${ }^{14}$ Shleifer and Wolfenzon (2002) use a similar idea to formulate investor protection in a formal model.
} 
where the first term is his dividend payoff if the expropriation is vetoed, times the probability of veto; the second terms is the sum of dividend and private gain if the expropriation goes through, times the probability of going through; the last two terms are the standard costof-theft in La Porta et al. (2002) and expected reputation cost from voting, respectively. The difference between the two costs is that $c$ measures the cost of expropriation from institutions that exist prior to the voting rule's adoption, while $r$ represents the incremental costs that are attributed to the disclosure of voting outcomes. ${ }^{15}$ Both costs will incur as long as the expropriation is proposed, irrespective of whether shareholders eventually veto it. To simplify the example, let the $p(v, s)=v s, v>0$ and $r(d, p)=\frac{1}{2} d p^{2}=\frac{1}{2} d(v s)^{2}, d>0 .{ }^{16}$ The equilibrium expropriation level the controlling shareholder proposes under the shareholder voting regime is

$$
s^{*}=\frac{1-\alpha}{k+2 v(1-\alpha)+d v^{2}},
$$

which is strictly lower than the equilibrium expropriation level under the regime with no shareholder voting. ${ }^{17}$ The first term of the denominator corresponds to the deterrence from general investor protection; the second term corresponds to the deterrence from veto; the third term corresponds to the deterrence from the reputation cost of disclosing the voting outcome.

Prediction 1: Mandatory voting on RPT leads to lower level of RPT.

Despite the intuitive theoretical argument, as noted in the Introduction, there are several reasons why the voting rule may not have a significant effect on RPT in practice. First, investors may choose not to actively exercise their voting rights if they are not convinced

\footnotetext{
${ }^{15}$ Another approach is to incorporate reputation cost from voting into the cost-of-theft function $c(k, s)$. To illustrate the specific effect of the voting rule, I deliberately separate the two costs in the expected payoff to the controlling shareholder. The parameter $k$ of $c(k, s)$, the general investor protection level, does not include the voting rule.

${ }^{16}$ Although the solution depends on the function form assumptions, the observation that the equilibrium expropriation level is lower under the shareholder voting regime is robust to the assumptions.

${ }^{17}$ Under the voting regime, the realized expropriation (on average) is even lower than the proposed level due to the probability of veto.
} 
that their individual vote may affect the voting outcome. Second, RPTs can serve a number of valid purposes that are independent from expropriation (Khanna and Yafeh (2007)). If shareholders lack the information or sophistication to identify RPTs driven by expropriation motives, or if "good" and "bad" RPTs are bundled in the same resolution, shareholders may not raise their concerns through voting even if they are aware of the potential expropriation. Third, some investors may be concerned about the negative side effects of casting an "against" vote, such as a deteriorating relationship with the controlling shareholder. Some of these problems may be reduced by the presence of information intermediaries, such as proxy advisors, who enjoy economies of scale in information gathering and may specialize in analyzing the value implications of RPTs. However, proxy advisors are known to have their own incentives problems. For example, they are accused of developing "one-size-fits" all recommendations as a way to avoid costly firm-specific analyses. Nor it is clear that they have the expertise to perform the in-depth analysis required to sort out the nature of complex RPT transactions, which are often accompanied by incomplete disclosures. ${ }^{18}$

Next, I investigate how the deterrence effect varies by the type of transactions. If shareholders vote selectively to filter out value-destroying transactions from the rest, the deterrence effect should be stronger on RPTs that are more susceptible to expropriation. The literature documents that financing RPTs that can transfer large amounts of cash outside normal operations may be key suspects. For example, Cheung et al. (2006)) examine the market reactions to RPT disclosures made by firms listed in Hong Kong and find the acquisition and sale of assets and equity are associated with significant negative stock return. Jiang et al. (2010) document that the controlling shareholders of Chinese listed firms use inter-corporate loans to tunnel away billions of RMB from the companies. To further understand what types of transaction raises shareholder concerns in my setting, I read in detail ISS reports for the shareholder meetings where RPT resolutions received "against" recommendation from ISS

\footnotetext{
${ }^{18}$ In addition, proxy advisors can be subject to other concerns such as conflict of interest due to their consulting businesses, lack of accountability and transparency, and significant pressure from organized labor groups (Ertimur et al. (2013), Larcker, McCall, and Ormazabal (2015), Li (2016))
} 
or were rejected by shareholders. The reports reveal that the primary determinant of the recommendation is whether the underlying transaction is justifiable given the company's normal course of business. Financial transactions, such as inter-corporate loans and the purchase or sale of assets, frequently raise concerns as they often exist independent from the companies' core business models ${ }^{19}$. In addition, unlike operating transactions such as sales of goods, the terms of financial transactions are more difficult to benchmark against arms-length standards. Indeed, the ISS reports often note the lack of adequate disclosures to help shareholders assess the validity of financing RPTs. The above argument lead to my second prediction:

Prediction 2: The reduction of RPTs following mandatory voting is primarily driven by financing RPTs.

If the RPT voting rule deters expropriation, it should raise corporate valuation (La Porta et al. (2002)). Ideally, enhanced voting rights should monotonically improve shareholder value, as rational shareholders will not vote to the detriment of shareholder value. In practice, however, a number of frictions may cause enhanced voting rights not to improve (or even destroy) shareholder value. For example, if shareholders do not adequately distinguish legitimate transactions from those aimed at their expropriation, the voting rule may risk disrupting the value-enhancing role of RPTs (Enriques (2015)). In addition, the voting rule may introduce a hold-up problem that negatively affects managerial incentive. For example, if a manager knows that her project choice could be overruled by shareholders, she may exert less effort to discover profitable investment projects ex ante (e.g., Aghion and Tirole (1997)). Ultimately, while the RPT voting rule is designed to protect minority shareholders, how the rule affects shareholder value remains an empirical question. I study this questions using two approaches. First, I examine how stock prices react to news related to the passage of the voting rule. If investors anticipate the voting rule to have an overall positive effect on

\footnotetext{
${ }^{19}$ My conversation with ISS analysts and an Indian corporate lawyer also confirms the observation.
} 
shareholder value, the stock prices should react positively to events that signal a higher the likelihood of the rule's adoption.

Prediction 3: The stock market responds positively to the news that signals the passage of mandatory voting on RPT.

Testing the above prediction speaks to investors' perceptions of the expected effect of the voting rule. However, it does not necessarily captures how the rule contributes to shareholder value ex post, when it is adopted and enforced. Thus following Black et al. (2015), I complement the event study by examining how the voting rule affect the association between RPT level and firm profitability. This association reflects the nature of the RPTs, which, as discussed earlier, can have an expropriation component and a value-enhancing component. While the expropriation component drives the association between RPT and profitability to the negative side ${ }^{20}$, the value-enhancing RPTs push the association to the positive direction. If the voting rule primarily curbs expropriation, I expect the association between RPT and firm profitability to increase (i.e. becoming more positive or less negative). In contrast, if the threat of shareholder dissent also affects the use of legitimate RPTs, the association between RPT and profitability may not increase, and may even decrease.

Prediction 4: Mandatory voting on RPT results in a stronger association between RPT level and firm profitability.

The literature posits a dynamic relationship between corporate governance and institutional holdings. While institutional investors as external monitors can promote good corporate governance (Aggarwal et al. (2011), Boone and White (2015), Appel et al. (2016)), they also prefer to invest in better governed firms in the first place (Ferreira and Matos (2008), Leuz et al. (2008)). I use the mandatory RPT voting setting as an exogenous shock to test whether greater voting rights attract more institutional investors. With relatively larger

\footnotetext{
${ }^{20}$ Certain types of tunneling, such as equity dilution and forced buyback ("freezeout"), do not necessarily affect firm ROA. See Atanasov, Black, Ciccotello, and Gyoshev (2010) for more discussion.
} 
stake, more sophisticated approaches to voting, and possibly more economies of scale due to holdings in many firms, institutions are more likely to benefit from the voting rights than individuals (Gillan and Starks (2000), McCahery, Sautner, and Starks (2016)). In addition, I expect the effect to be stronger for foreign institutional holdings. Local investors, because of proximity, have a comparative advantage in acquiring information and accessing informal monitoring mechanisms, such as private conversations (Giannetti and Simonov (2006), Kho et al. (2009)). Foreign investors, on the other hand, may rely more on formal investor protection mechanisms such as shareholder voting.

Prediction 5: Both domestic and foreign institutional investors increase their holdings following mandatory voting on RPT. The increase is more pronounced for foreign institutional investors.

\section{How Are RPT Resolutions Voted?}

\subsection{Descriptive Statistics}

As a first step of my analysis, I examine how RPT resolutions were voted after the rule came into effect in 2014. Inspecting realized voting outcomes provide direct evidence of whether and how shareholders used their enhanced voting right to identify questionable RPTs, which in turn may help complement and interpret the subsequent analyses on the voting rule's deterrence effect.

I acquire voting data from Institutional Shareholder Services (ISS), a leading international proxy advisor. For each resolution, the data set contains information about date, type of resolutions, manager and ISS recommendation, and voting outcome. The data set covers 660 and 762 Indian firms for which ISS provided voting guidelines in calendar year 2014 and 2015, respectively (approximately 10\%-15\% of the total number of firms listed in India at that time). During this period, 348 RPT resolutions from 226 firm-years (206 unique 
firms) were voted. I then merge the voting dataset with the Prowess database to obtain financial information about the sample firms. Table I provides descriptive statistics. Panel A compares 348 RPT resolutions (at the firm-party level) to the other resolutions voted in the same firm-years. The within-firm-year approach naturally control for firm-specific characteristics (e.g., ownership composition) that may affect the voting outcomes. Panel B reports summary statistics of firm characteristics.

The first notable finding from Table I is that RPT resolutions are more likely to receive shareholder dissent relative to other resolutions. The average percentage of votes against RPT resolutions is $8.03 \%$, versus $1.85 \%$ for non-RPT resolutions. $9.77 \%(4.02 \%)$ of RPT resolutions receive at least 25\% (50\%) against votes of the votes cast, while the corresponding frequencies of non-RPT resolutions is only $0.56 \%$ (0.30\%). The difference between RPT resolutions and others is partly driven by the "majority-of-minority" feature of RPT resolutions that prohibits controlling shareholders who are connected to the related parties from voting. As shown in Panel A, votes cast divided by shares outstanding is about $33 \%$ for RPTs versus about $70 \%$ for other resolutions, mainly due to the absence of controlling shareholders. However, even after controlling for this effect, RPT resolutions receive twice as large voting dissent. After accounting for differences in eligible votes, the $8.03 \%$ of "votes against" in Panel A translates to about $2.7 \%$ of total shares $(=8.03 \% \times 33.46 \%)$, versus about $1.3 \%$ for non-RPT resolutions $(=1.85 \% \times 70.54 \%)$. Taken together, the strong dissent on RPT resolutions is attributed to both the "majority-of-minority" feature and that minority shareholders cast against votes actively.

A second key finding in Table I is that RPT resolutions do fail $(7.76 \% \text { of them })^{21}$, suggesting that the threat of a RPT resolution being blocked by shareholders under the voting regime is real and thus making the evidence of a deterrence effect (examined later) more

\footnotetext{
${ }^{21}$ As mentioned earlier, the requisite majority to pass RPT resolution was initially set as $75 \%$ by both the 2013 Act and the SEBI's rule, and was revised to 50\% in September 2015. In my sample, the revision only affects the second half of financial year 2016 (April 2015-March 2016). As a result, the number of failed RPT resolutions is in between the number of resolutions with $25 \%$ against and with $50 \%$ against votes.
} 
plausible. $^{22}$

\subsection{Mini Case Studies}

\section{Case 1: United Spirits Ltd.}

United Spirits was the flagship company of the United Breweries Group, an Indian beverage conglomerate. The group was controlled by Vijay Mallya, an entrepreneur famous for his extravagant lifestyle (Stacey (2017)). In 2012, Diageo, a British alcoholic beverage giant, agreed to acquire a majority stake at United Spirits by purchasing shares from the United Breweries Group. By 2014, Diageo had become the controlling shareholder of United Spirits, while Vijay Mallya remained the Chairman of the company.

In November 28, 2014, United Spirits held an extraordinary shareholder meeting to seek approval for 11 related party transaction resolutions. The proposed transactions range from loans, sales of goods, transferring assets, trademark licensing, and advertising deals. The promoter group (including Diageo and Vijay Mallya's UB group), which collectively held over $55 \%$ of outstanding shares, abstained from the voting because they were connected to the related parties. To the surprise of the promoters, minority shareholders expressed a tremendous level of dissent by rejecting 9 of the 11 RPT resolutions. Among the rejected resolutions, 5 received over $50 \%$ against votes of votes cast. ${ }^{23}$ In response to the voting outcome, United Spirits scaled down RPTs in several categories such as loans, dividends and guarantees, providing substantially more disclosures in its subsequent annual report. ${ }^{24}$ At the same time, the company booked additional loan loss provisions for several related parties,

\footnotetext{
${ }^{22}$ Failed RPT resolutions are not a necessary condition for the deterrence effect to occur. In equilibrium, managers will not propose resolutions not expected to pass. Thus, mandatory voting may be effective even if there is no evidence of ex post voting dissent. In practice however, when a new voting rule is adopted, some managers may not immediately and fully anticipate shareholders' reaction and can propose resolutions that are rejected by shareholders. Studies on "say on pay" show that in the early years there are always a few cases of failed say on pay proposals (e.g., Ferri and Maber (2013), Ertimur et al. (2013)).

${ }^{23}$ The requisite majority was $75 \%$ at the time.

${ }^{24}$ An excerpt of the RPT disclosure and voting outcomes is shown as an example in Internet Appendix.
} 
suggesting the intention to write off some existing inter-corporate lending. In financial year 2016, United Spirits further expanded the disclosure of RPTs by providing a brief justification for each non-arms-length transaction.

After the embarrassing defeat, the conflict between Vijay Mallya and Diageo intensified. An internal investigation led by Diageo found that Vijay Mallya had been improperly trans-

ferring United Spirits funds to his struggling Kingfisher Airlines and other businesses (Rana (2016)). The board eventually forced Vijay Mallya to resign from Chairman, conditional on a $\$ 75$ million severance package and other benefits. However, the Debt Recovery Tribunal halted the severance package at the request of the creditors who pursued debt recovery from the companies Vijay Mallya managed. In March 2016, Vijay Mallya allegedly left India to escape the law suits right before his arrest warrant was issued.

\section{Case 2: Repco Home Finance Ltd.}

Repco Home Finance is a listed housing finance company that provides home loan products to individual borrowers. The company is promoted by Repco Bank, a government controlled bank with $37 \%$ ownership in Repco Home Finance. Repco Home Finance has historically engaged in large related party transactions, primarily in the form of receiving loans from Repco Bank. However, the structure or the interest rate of those borrowings were not disclosed in annual reports.

In 2015, Repco Home Finance sought shareholder approval for related party transactions with Repco Bank. The resolution covered up to INR 30 billion of loans, overdraft facilities, deposits, interest, and rent payment. However, neither the minority shareholders nor the proxy advisors were convinced of the necessity or the fairness of the transactions. For example, ISS expressed concern over the vague disclosure of the RPTs, stating that "the company has provided limited disclosure on the loan arrangement and rent agreement to be carried out under the proposed mandate. The details of these transactions to be conducted and processes through which ensure the fairness of these transactions have not been made 
available." The shareholders rejected the resolutions in the annual meeting in September 2015, and again in a special voting in December 2015. In March 2016, the resolution finally passed with the requisite majority after a revision that cut the total transaction amount (including the existing transactions) from the original INR 30 billion to INR 6.5 billion. In the 2016-2017 annual report, Repco Home Finance enhanced the disclosure on its borrowing positions by tabulating the distribution of interest rates for each maturity interval and loan type. The report also included a detailed discussion of the firm's RPT policies. Notably, the RPT footnote shows that the closing balance of the accounts with Repco Bank had little change from the previous year, suggesting that almost no new transactions were carried out during the period.

\subsection{The Determinants of Voting Outcomes}

Next, I explore how RPT resolutions are voted by regressing voting outcomes to lagged firm characteristics. The first dependent variable is the percentage of against votes of total votes cast. An alternative dependent variable is an indicator equal to one if the resolution receives more than $25 \%$ against votes, and zero otherwise. The independent variables include lagged RPT (scaled by total assets), natural log of total assets, lagged ROA and lagged excess returns, promoter ownership, domestic institutional ownership, and foreign institutional ownership. Ideally, I would like to also include the characteristics of each proposed transaction, but this data is not available. I use linear models with OLS for continuous outcome variables and use logit models with maximum-likelihood estimation for binary outcome variables. Since one firm can have multiple RPT resolutions, I cluster standard errors at firm level to account for within-firm correlation in residuals.

Table II reports the results. Column 1 shows that, conditional on size, performance and ownership structure, firms with higher RPT levels in the past receive more "against" votes on average. In Column 2, I split total RPT into the operating component and the financing component. As detailed in the Appendix, I classify loans, purchasing/selling of assets or 
investment, dividends, interest payments, and capital issuance as Financing RPT. The rest are classified as Operating RPT. Interestingly, Financing RPT has significant predictive power on shareholder dissent while Operating RPT does not. A one standard deviation (0.113) increase in lagged Financing RPT is associated with a $3.2 \%$ increase in the percentage of against votes, corresponding to a 40 percentage difference from the unconditional mean (8.03\%). In Column 3, I include the indicator of ISS "against" recommendation as an additional independent variable. The purpose is to see whether the association between past RPT level and voting outcome still holds conditional on ISS recommendation. Notably, receiving "against" recommendation from ISS is associated with an $13.9 \%$ increase in against votes. However, even controlling for ISS recommendation, lagged Financing RPT continues to predict the probability of shareholder dissent. In Column 4-6, I use the indicator of receiving more than $25 \%$ against votes as an additional measure of shareholder dissent. The results from logit regression are consistent with Column 1-3. To interpret the magnitude, take the estimates in Column 5 for example. Setting all variables to sample mean, the conditional probability of receiving more than $25 \%$ against votes is $5.3 \%$. Holding everything else constant, raising lagged Financing RPT by one standard deviation is associated with an over $100 \%$ increase in the conditional probability (to $11.0 \%$ ).

Motivated by the observation that ISS recommendation strongly predicts voting outcomes, in Column 7 and 8, I examine the determinants of ISS voting recommendations. The result shows that only lagged Financing RPT is positively associated with the probability of receiving against recommendation.

Overall, the results suggest that voting shareholders and proxy advisors are more likely to oppose resolutions from firms with high financing RPTs in the past. This suggests either that they use a high level of financing RPTs in the past to identify questionable transactions, or, more likely, that firms with high financing RPTs tend to submit resolutions that shareholders and proxy advisors view as value-destroying.

Another interesting finding from Table II is that foreign institutional ownership is strongly 
and positively associated the probability of shareholder dissent. In contrast, the association between domestic institutional holdings and the probability of shareholder dissent is not significant. The result suggests that foreign investors on average are more likely to cast against votes to RPT resolutions (even after controlling for recommendations by ISS, which are likely to be followed by many foreign investors) ${ }^{25}$ The significantly negative coefficient on Past ROA and shareholder dissent indicates that shareholder are more likely to vote against RPT resolutions when firm performance is weak. One possible explanations is that poor profitability signals that firm profits are tunneled away through RPTs (Bertrand et al. (2002)). Another possibility is that when firms become less profitable due to exogenous reasons, controlling shareholders have greater incentives to expropriate firm resources, because the opportunity cost of expropriation (i.e. investing in the firm) is lower (Johnson et al. $(2000))$.

To sum up, the descriptive analysis offers two important observations. First, voting dissent on (and proxy advisors' scrutiny of) on RPT resolutions is substantially higher than non-RPT resolutions. The higher dissent is explained by both the "majority-of-minority" feature of the RPT voting rule and that minority shareholders more actively vote against RPT resolutions. Second, the voting outcomes depend on the extent to which firms used RPTs, and especially financing RPTs, in the past, consistent with the evidence that such RPTs are more susceptible to be used by controlling shareholders to expropriate minority shareholders' wealth, and that firms with large use of financing RPT draw larger scrutiny.

\footnotetext{
${ }^{25}$ However, the result should not be interpreted as that domestic institutions do not actively vote on RPT resolutions. Given the relatively low holdings of foreign institutions, the observed shareholder dissent is likely attributed to both domestic and foreign institutions.
} 


\section{The Deterrence Effect of RPT Voting}

\subsection{Sample and Research Design}

Detecting the overall deterrence effect of shareholder voting is challenging because the counterfactual cannot be observed. In other words, given the voting requirement, it is impossible to observe how much RPT will be carried out in the absence of the voting requirement. To tackle this challenge, I use a difference-in-difference (DID) design that compares the change in RPTs between treated firms (i.e. those affected by the rule) and control firms (i.e. those not affected by the rule). The DID design effectively assumes that the post-regulation pattern in RPT for control firms is indicative of what we would have observed for treatment firms absent the voting requirement. Because all publicly listed firms were subject to the new voting requirement, I exploit the fact that the mandatory voting requirement only applies to "material" RPTs, where materiality is defined by the size of the transactions.

Specifically, I first classify as "material" all the RPTs taking place before the new rule that would have been classified as material transactions under the new rule. As detailed in Appendix A, for firm $i$ in financial year $t$, a related party of firm $i$ is classified as "material" if firm $i$ 's total transaction amount with the party during year $t$ exceeds $10 \%$ of firm $i$ 's most recent revenue. The "material RPT" for firm $i$ year $t$ is the sum of transactions with all "material" parties. ${ }^{26}$ Appendix B provides a simple example to illustrate the construction.

Next, I classify as "treated" firms all firms that had "material" transactions every year during the three-year period prior to the new rule. All other firms are defined as "control" firms. ${ }^{27}$ The idea behind this classification is that firms consistently engaging in material RPTs in the past are likely to continue the existing practice in the absence of regulatory change. When the voting rule comes into effect, these firms are more likely to be affected.

\footnotetext{
${ }^{26}$ One caveat of this approach is that the threshold of voting rule is by nature based on the expected contractual amount, not realized transaction volume (which forms the data I use). Thus, my measure of "material" RPT is a proxy for the RPT contracts that would be labelled as "material".

${ }^{27}$ In a robustness test, I obtain similar results when including in the control group only firms without any material RPTs in the three-year period prior to the new rule.
} 
Firms that never or infrequently have material RPT are less likely to be affected. In other words, I classify firms into treated and control based on how likely their existing RPT practices are impacted by the rule. ${ }^{28}$ If the voting rule deters RPT, then the firms most affected by the rule (treated firms) should experience a decrease in RPTs compared to the firms least affected by the rule (control firms). ${ }^{29}$

I obtain data on financial statements, stock returns, equity ownership and corporate governance from Prowess, a database maintained by the Center for Monitoring the Indian Economy (CMIE). Prowess covers both listed and large unlisted firms in India. The related party transactions data are captured by CMIE from the RPT disclosure in annual reports mandated by Accounting Standard 18 (AS-18). AS-18 requires listed firms to disclose in the footnotes of financial statements the aggregate amount transacted with each related party for each type of transactions. The United Spirits RPT footnote shown in Internet Appendix is an example of this disclosure.

To construct the sample, I focus on a five-year window around the adoption of the mandatory voting rule. The pre-treatment period consists of 2012, 2013 and 2014, and the post-treatment period includes 2015 and $2016 .{ }^{30}$ I start with listed domestic Indian firms in the Prowess Universe that have financial information from 2012 to 2016. I delete observations with missing key variables necessary for the regressions. To focus on firms with significant RPT volume, I exclude firms whose average total RPT volume is less than $1 \%$ of total assets

\footnotetext{
${ }^{28}$ Since the treated and control firms differ in the probability of receiving treatment, my approach is essentially a "fuzzy" difference-in-difference design. See Armstrong, Glaeser, and Huang (2017) for more discussion and Ferri and Li (2017) for another application. Similarly, Atanasov, Black, et al. (2016) denote DID strategies with continuous cross-sectional variation as "DID-continuous". For the ease of notation, I still use the term "treated" to describe firms who are more likely to be affected by the rule and the term "control" for the rest of the firms.

${ }^{29}$ One caveat is that the theory predicts that mandatory voting deters the level of expropriation through RPT. However, a reduction in expropriation may not always translate into a reduction in the level of RPT. The controlling shareholder may reduce expropriation by adjusting the term of RPT without changing the level. Thus, if empirical result does not show that RPT level drops, one cannot conclude that the voting rule does not deter expropriation without further investigation.

${ }^{30}$ Because India financial years usually start in April 1st and end in March 31st, the pre-treatment period effectively starts in April 2011 and ends in March 2014; the post-treatment period starts in April 2014 (when the voting rule first came into effect) and ends in March 2016.
} 
in the pre-treatment period. The final sample consists of 7,743 firm-year observations from 1,716 unique firms (360 treated firms and 1,356 control firms).

To estimate the deference effect, I use the following fixed effects regression model

$$
Y_{i t}=\beta_{1} \text { Treated }_{i} \times \text { Post }_{t}+\gamma X_{i t}+\eta_{t}+\delta_{i}+\epsilon_{i t},
$$

where $Y_{i t}$ is the outcome of interest for firm $i$ in year $t$. Treated $i$ is a dummy variable that equals 1 if firm $i$ belongs to the treatment group as defined above. Post $t_{t}$ is an indicator that takes value of 1 for observations in financial year 2015 and 2016, and 0 otherwise. $X_{i t}$ is a vector of control variables to control for observable firm characteristics. I use two sets of control variables. The first set, which I call basic controls, includes total assets (log), leverage and, lagged annual excess return. ${ }^{31}$ As discussed in detail below, the second set, which I call additional controls, is used to account for contemporaneous changes in corporate governance regulations. The definitions of all variables are presented in Appendix A. $\eta_{t}$ and $\delta_{i}$ represent year fixed effects and firm fixed effects. $\epsilon_{i t}$ is the error term. Treated T $_{i}$ and Post $_{t}$ do not enter the regression separately because they are absorbed by firm fixed effects and year fixed effects, respectively. In all specifications, standard errors are clustered at the firm level. The key coefficient of interest is $\beta_{1}$, which measures the change in $Y_{i t}$ following the RPT voting rule for the treated group relative to the control group.

With the additional controls, I explicitly control for contemporaneous regulatory changes that may have affected treated and control firms differently. While the 2013 Act introduced a series of changes in corporate governance, I do not expect them (besides the voting rule) to have a first order impact on RPT. I nevertheless include the following control variables

\footnotetext{
${ }^{31}$ In the baseline regression, I do not control for accounting profitability and ownership variables, as they will be later used as outcome variables. Including potential outcome variables as controls may give biased results. As a robustness check, I nontheless report the results after including one-year-lagged ROA, promoter ownership and institutional ownership in Internet Appendix. In addition, in my matched sample analysis (also in Internet Appendix), I match on pre-treatment ROA and ownership variables, among other characteristics.
} 
for four important provisions: mandatory auditor rotation ${ }^{32}$, mandatory woman director ${ }^{33}$, executive pay cap ${ }^{34}$, and mandatory corporate social responsibility (CSR) expenditure ${ }^{35}$. To account for these changes, I include the following control variables: an auditor turnover indicator, the percentage of new directors, board independence, auditing committee independence, the natural logarithm of CEO (or the highest paid executive) total pay and CSR expenditure (scaled by total assets). Because only $75 \%$ of the observations in the sample have non-missing data for all the additional control variables, I first report regression results without additional controls for the full sample and then with additional controls for the smaller sample.

The key identification assumption of the DID framework is the parallel trend assumption, which states that the outcome variable of treated and control firms would trend similarly in the absence of the treatment. Although this assumption cannot be directly verified, I use the following alternative DID regression to examine whether the trends between treated and control firms differ significantly prior to the treatment

$$
Y_{i t}=\sum_{k=1}^{5} \beta_{k} \text { Treated }_{i} \times F Y(k)_{t}+\gamma X_{i t}+\eta_{t}+\delta_{i}+\epsilon_{i t}
$$

\footnotetext{
${ }^{32}$ The mandatory auditor rotation provision under the 2013 Act forbid listed firms and large unlisted firms from having the same external auditing firm for 10 consecutive years. In addition, firms cannot have the same individual as external auditor for more than 5 consecutive years. The provision first went into effect in April 1st, 2017, which means firms that have the same auditing firms for more than 10 consecutive years by April 2017 should switch auditing firm in financial year 2018. Therefore, this regulation does not directly affect my sample period.

${ }^{33}$ The 2013 Act and a SEBI rule require all listed firms to appoint at least one woman on their boards (either as insider or outsider) by April 2015. Although the provision may not have a strong impact on overall board composition, I control for the percentage of newly appointed director, board independence and auditing committee independence as precautionary measures for the potential confounding effect. The other provisions in the 2013 Act related to board composition were largely already in effect for listed companies as per the existing listing agreement.

${ }^{34}$ The provision in the 2013 Act mandates that the total compensation to managers and directors must not exceed $11 \%$ of the company's net profits during the financial year. For individual manager/director, the threshold is $5 \%$ for managers and whole-time directors, and $1 \%$ for part-time directors. In addition, the provision gives specific accounting guidelines (in addition to India GAAP) for calculating the net profit that the pay cap is based on.

${ }^{35}$ Large listed companies are required to spend at least $2 \%$ of net profits for CSR purposes. See Manchiraju and Rajgopal (2017) for a detailed discussion.
} 
where $F Y(k)$ is an indicator variable for each of the five fiscal year. For example, $F Y(1)$ equals 1 for observations in financial year 2012 (first year in the sample) and otherwise equals $0 ; F Y(5)$ equals 1 for observations in financial year 2016 and otherwise equals 0 . This approach allows me to examine whether, conditional on fixed effects and control variables, the treated firms and the control firms have significant difference in RPT trend prior to the treatment. As will be discussed later, Figure I shows that the treated group and the control group follow similar trends prior to the voting rule's adoption. In addition, as will be described later, I repeat the main tests based on a sample where treated firms and control firms are matched on observable characteristics.

\subsection{Does Mandatory Voting Affect RPT?}

Table III, Panel A, compares pre-treatment RPT variables and firm characteristics between treated and control firms. As expected, treated firms have much higher RPT volume than control firms. Total RPT, the ratio of total RPT volume to lagged total assets, is 0.56 for treated firms and 0.21 for control firms. The difference comes entirely from material RPTs, representing 0.49 of lagged total assets for treated firms, versus 0.14 for control firms. For both treated and control firms, total RPT are split about equally between operating RPTs and financing RPTs. In terms of firm characteristics, treated firms are significantly larger, with average total assets (INR 29.8 billion) around 1.4 times that of the control firms (INR 21.3 billion). Treated firms also have lower profitability, as measured by ROA, higher leverage, higher promoter ownership and lower domestic institutional ownership, with a slightly higher ratio of foreign to domestic institutional ownership.

Panel B reports the changes in average RPT variables from the pre- to the post-treatment period. Notably, after the voting rule came into effect, the average Total RPT drops significantly for the treated group, from 0.56 to 0.45 of lagged total assets, while remaining almost constant for the control group at 0.21 . The reduction of treated group's Total RPT is entirely driven by the drop in Material RPT, from 0.49 to 0.37 , with both Operating RPT 
and Financing RPT contributing about equally to the drop. Interestingly, treated firms also experience an increase in total institutional ownership relative to the control firms, driven by foreign institutional investors.

Table IV reports the result of estimating equation (1) for three outcome variables: Total RPT, Material RPT and Non-Material RPT. Column 1 and 2 reports the result for Total RPT. The coefficient on Treated $\times$ Post is -0.079 with basic control variables and -0.076 with additional control variables, significant at $1 \%$ level. This suggests that the treated group experiences an almost 0.08 drop in Total RPT around the voting rule's adoption, compared to the control group. The magnitude of the drop is economically significant, approximately $14 \%$ of the average Total RPT of the treated group prior to the treatment $(0.56)$.

In Column 3 and 4, I replace the outcome variable with Material RPT. Compared to the control group, the treated group's Material RPT decreases by 0.106 with basic control variables and 0.097 with full controls, significant at $1 \%$ level. This result confirms that the observed drop of Total RPT is entirely driven by Material RPT. Indeed, the treated group experiences an increase in Non-material RPT relative to the control group (Column 5 and 6). The increase (0.015), though statistically significant, is relatively small compared to the decrease in Material RPT. This implies that only a small proportion of the reduction in material transactions is offset by an increase in non-material transactions, alleviating concerns that treated firms somehow circumvented the rule by replacing material RPTs with non-material RPTs. Overall, the results from Table IV are consistent with Prediction 1 that the RPT voting rule has a deterrence effect on the level of RPT.

Next, I examine what type of transactions are primarily responsible for the observed reduction in RPTs. Table $\mathrm{V}$ presents the regression result after decomposing Total RPT into Operating RPT and Financing RPT. Financing RPT are defined as the sum of loans, investment, purchase and sale of assets, interest payments and dividend payments between related parties. The remaining RPTs are labeled as Operating RPT, including items such as sales of good and service, raw material expense, and rent payment. Column 1 and 2 shows 
that Operating RPT witnesses a modest drop for the treated group relative to the control group, insignificant at $10 \%$ level. In contrast, Columns 3 and 4 report that treated firms have a sharp decrease in Financing RPT compared to the control firms (0.051 with basic control and 0.040 with additional controls). The magnitude of the DID estimate is about 15-20\% of the pre-treatment level (0.26). Consistent with Prediction 2, these results suggest that the RPT voting rule's deterrence effect comes primarily from financial transactions.

\subsection{Robustness Tests}

To provide corroborative evidence for the parallel trend assumption, I estimate the trend of difference between treated firms and control firms with equation (2). Figure I presents the results, confirming the results in Table IV and V. ${ }^{36}$ The trend of the point estimates can be thought as the difference in RPTs between treated and control group, adjusted for firm characteristics. The graphs show that both Total RPT and Financing RPT trend similarly for treated firms and control firms prior to the treatment, and diverge significantly after the treatment. Operating RPT, however, does not have significant divergence both pre- and post-treatment, except in financial year 2012, consistent with the result that the effect is less pronounced for Operating RPT.

Another complication arises when the treated and control firms have different average levels of outcome variables. In this case, the estimated effect is sensitive to the functional form of the outcome measurement. ${ }^{37}$ To address this concern, I use log(1+RPT level) as an alternative measurement for RPT level, where the unit of RPT level is INR million ${ }^{38}$. The result, reported in Table AVII in Internet Appendix, confirms that the results in Table IV

\footnotetext{
${ }^{36}$ The estimates are based on the specifications with both basic and additional control variables. The RPT level in 2014 is set as the reference point.

${ }^{37}$ For example, assume the interested outcome of a treated firm decreases from 10 to 8 , while that of a control firm decreases from 2 to 1 . If the difference is measured in absolute term, the DID estimate will be -1 . If the difference is measured in percentage change, the DID estimate will be $30 \%(-20 \%-(-50 \%))$, in which case even the sign of the estimate changes.

${ }^{38}$ The change of $\log (1+\mathrm{RPT}$ level $)$ is a monotonic function of the percentage change of RPT level.
} 
and $\mathrm{V}$ are robust to the functional form of RPT measurement. Panel B shows the results are robust to using lagged total revenue to scaled RPT variables.

As mentioned earlier, the results are insensitive to using an alternative definition of control group where I only include firms without any "material" RPTs in pre-treatment period. The results are reported in Internet Appendix Table AVIII. In addition, Table AIV confirms that the results are robust to including lagged ROA and ownership characteristics as control variables.

\subsection{Value Implication}

The results thus far suggest a deterrence effect of the mandatory voting rule on the volume of RPTs, especially for financing RPTs. In this section, I investigate whether this effects results in improved firm value or performance, using two different approaches. First, I examine how stock prices react to events indicating greater likelihood that the mandatory voting rule will be passed. Next, I explore how the association between RPT level and firm performance changes around the rule's adoption.

\subsubsection{Market Response to Mandatory Voting on RPT}

My first approach uses short-window stock return to gauge the perceived value effect of the voting rule. If investors believe the rule will enhance shareholder value, stock prices should react positively to the news signaling the rule's passage. Combining the DID framework with the event study method, I compare the short-window stock returns between treated firms and control firms around the key legislative events that lead to the passage of the voting rule.

Following Manchiraju and Rajgopal (2017), I use major milestones in the legislative history of the Companies Act 2013 to identify key events that signal the passage of the bill. The Act was first introduced to the Indian parliament on August 2009. After years of debates and revisions, the Act was approved by Lok Sabha (the lower House of the Indian 
Parliament) on 18th December 2012. The Rajya Sabha (the upper House of the Indian Parliament) approved the Act on 8th August 2013. On 29th August 2013, the Act received the President's assent and became law. Therefore, the first three events I use are the approval by Lok Sabha, the approval by Rajya Sabha and the President's assent. The fourth event I use is the announcement of the SEBI's rule that includes mandatory voting on RPT into the exchanges' listing standard on April 17, 2014.

$$
E R_{i}=\beta_{1} \text { Treated }_{i}+\gamma X_{i}+\epsilon_{i},
$$

where $E R_{i}$ is the three-day excess return, measure as the difference between raw return and value-weighted return of the data universe accumulated over the three trading days $(-1,0$, +1 ) around the event. Treated $_{i}$ is a dummy variable that equals 1 if firm $i$ belongs to the treatment group. Since the events took place prior to the voting rule's actual adoption, for the event study, I classify firms into treated and control groups based on the most recent three years prior to the events (instead of the adoption). To account for other forces that may drive the cross-sectional variation in market response, I include the following control variables (represented by $X_{i}$ ). First, I control total assets (log) and book-to-market ratio, two variables that could explain variations in cross-sectional returns. Second, I control for the potential influence of the contemporaneous corporate governance provisions discussed earlier. Audit Switch (Past 3 Years) is a dummy variable taking value of 1 if the firm have switched external auditor in any of the past three years. If a firm switched auditor from 2011 to 2013, it is less effected by the rule when it comes into effect in 2017, because firms are only required to change auditor once every 10 years. To account for the provisions on board composition and executive pay, I include board independence and the natural logarithm of CEO total pay, measured before the events. Lastly, I control for CSR Coverage, a dummy variable equal to 1 if the firm is expected to be affected by the mandatory CSR expenditure rule. ${ }^{39}$ The above specification can be interpreted as a difference-in-difference design around

\footnotetext{
${ }^{39}$ The applicability of the rule depends on whether the firm passes certain thresholds on revenue (INR 10
} 
the events, since the cumulative excess return can be interpreted as the change in shareholder value.

Although in theory each event could raise the perceived probability of mandatory RPT voting, the impact of each individual event may not be equally significant. To increase the power of the test, I also compound the cumulative returns across the four events (12 trading days) and use the 4-event-cumulative excess return as the outcome variable. To make the results comparable across different events, I only include firms that have data for all four events, resulting in 1,212 unique firms.

Table VI reports the results from the event study. Columns 1-4 report the differential market reactions of the treated and control groups to each of the four events. The coefficient for Treated is positive and significant for the first two events, which correspond to the passage of the Companies Act 2013 in the lower and upper House of the Indian Parliament. For event 3 and 4 , the coefficients are positive but not statistically significant. One possibility is that the later events did not provide new information to the market following the bill's passage in the Parliament. In Column 5, I aggregate the four events by using the excess return accumulated over the 4 events (12 trading days). The coefficient of Treated is 0.038 , suggesting that treated firms on average experience a $3.8 \%$ higher return than control firms over the 12 trading days when the probability of adopting the RPT voting rule increased significantly. The results are consistent with the prediction that shareholders on average expected mandatory voting on RPT voting to have a positive impact on shareholder value.

\subsubsection{Change in the Association between RPT and Firm Profitability}

The analysis on market response provides evidence that investors expect that the RPT voting rule will raise shareholder value. However, that approach does not address whether and how the voting rule contributes to shareholder value ex post. To fill this gap, I study how

billion), profit (INR 50 million), or net worth (INR 5 billion). If a firm met one of the thresholds given its most recent financial information before the events, I set CSR coverage to 1. 
mandatory voting on RPT contributes to firm profitability, measured by return on assets. As stated in Prediction 4, if the voting mechanism successfully filters out expropriation, I expect the association between RPT and firm performance to increase after the rule's adoption. To test this prediction, I modify the baseline DID equation as follows

$$
\begin{aligned}
R O A_{i t}= & \beta_{1} R P T_{i t}+\beta_{2} R P T_{i t} \times \text { Treated }_{i}+\beta_{3} R P T_{i t} \times \text { Post }_{t}+\beta_{4} R P T_{i t} \times \text { Treated }_{i} \times \text { Post }_{t} \\
& +\beta_{5} \text { Treated }_{i} \times \text { Post }_{t}+\gamma X_{i t}+\eta_{t}+\delta_{i}+\epsilon_{i t},
\end{aligned}
$$

where $R O A_{i t}$ is the outcome of interest for firm $i$ in year $t . R P T_{i t}$ is the RPT variable of interest. Other variables follows Equation (1) with detailed definition presented in Appendix A.

Table VII reports the results. In Column 1 and 2, I explore the association between Total RPT and ROA. In next two columns and the last two columns, I swap the RPT variable with Operating RPT and Financing RPT, respectively. Across the six columns, the first row shows that the coefficients of RPTs variables are positive in five specifications but only statistically significant in two of them, suggesting a weakly positive association between RPT and firm performance prior to the treatment. The main interest is the coefficient of the triple interactions term, $R P T \times$ Treated $\times$ Post, which measures how much the association between RPT and profitability changes around the treatment for the treated group relative to the control group. Column 1 shows the coefficient of the triple interaction is positive and significant at $5 \%$ level, implying that association between Total RPT and ROA increased by 0.028 in the treated firms compared to the control firms. Column 2 shows similar results with additional control variables. Column 3 and 4 report that the coefficient is not significant when Operating RPT is used as the RPT variable. Column 5 and 6 , however, show that the association between Financing RPT and ROA increases significantly in the treated firms relative to the control firms (by 0.064 and 0.080 ), even when additional controls are included. Overall, these findings suggest that, after the voting rule's adoption, 
RPTs, especially financial transactions, have on average a more positive contribution to the firm profitability. This is consistent with the conjecture that mandatory voting on RPT, on average, filtered out value-destroying RPTs while preserving value-creating RPTs.

\subsection{Institutional Ownership}

The last part of my main results focuses on how the voting rule affect institutional ownership. I use the baseline DID regression outlined in equation (1) to examine how institutional ownership changes for the treated firms relative to the control firms around the adoption of the RPT voting rule. Table VIII presents the results. Column 1 shows that, compared to the control group, the treated group's total institutional ownership increases by 0.014 , approximately $9.1 \%$ of the pre-treatment level of 0.15 . In Column 3 and 5 , I break down the total institutional ownership to the domestic component and the foreign component. The coefficients is positive for both outcome variables, but only significant for foreign institutional holdings, suggesting that the observed effect on total institutional holdings is primarily driven by foreign institutions. The increase in foreign institutional holdings (0.008) represents a $21 \%$ percentage change from the pre-treatment level of 0.039 . Columns 2, 4 and 6 confirm the findings with additional control variables. The results in Table VIII are consistent with the prediction that the RPT voting rule make firms with material RPTs more attractive to institutional investors, especially foreign ones, presumably because of reduced expropriation risk under the new regime.

\subsection{Additional Tests}

\subsubsection{Propensity Score Matching and Entropy Balancing}

To further alleviate the concern that my results are driven by pre-treatment differences in firm characteristics between treated and control firms, I match a subset of control firms to the treated firms with similar characteristics. Specifically, I use the propensity score 
matching (PSM) based on the following characteristics measured in each pf the three pretreatment year: total assets (log), leverage, ROA, excess returns, and promoter ownership (i.e. 15 covariates in total). I perform a one-to-one nearest-neighborhood PSM matching without replacement. The matching procedure leaves 351 treated firms and the same number of control firms. The balance of the matched sample's average firm characteristics prior to the treatment is presented in Table AIX Panel A in Internet Appendix. I then estimate the DID regressions based on the matched sample. The results are reported in Table AX. Across various outcome variables, the results are comparable to the full-sample analysis, suggesting that observable pre-treatment differences between treated firms and control firms do not drive the main results. As an sensitivity check, I perform the nearest-neighborhood matching on the Mahalanobis distance of the covariates (instead of the propensity score) and obtain similar results.

As an alternative to matching, I use the entropy balancing technique (Hainmueller (2012)) that reweighs observations to achieve weighted covariate balance. Compared to PSM, entropy balancing directly targets covariate balance (in mean and higher moments) and assigns continuous weights to units. I base the entropy weighting on the mean and variance of the same 15 covariates as in PSM. The comparison of reweighed means are reported in Table AIX Panel B. Table AXI confirms that the weighted regression results are qualitatively similar to the main analyses and PSM.

\subsubsection{Placebo Test}

To provide more support for parallel trend assumption, I perform placebo tests where I estimate the DID regression with a pseudo-treatment event date. The idea is that if the treated firms and control firms would have similar trends in outcome variables in the absence of the treatment, a placebo test with a pseudo-treatment event date should give null results. A challenge for my setting is that firms may react to the voting rule prior to the rule's adoption. Although the voting rule was passed in 2013 and implemented in 2014, it was 
first introduced to the Parliament in 2009. It is possible that from 2009 to 2014 some firms gradually react to the rule in anticipation of its passage. ${ }^{40}$ Furthermore, the revelation of the Satyam Scandal in 2009 may in itself pressure firms to adopt better corporate governance practices. Therefore, I use the window from financial year 2004 to 2008 for the placebo test, with 2007 and 2008 labelled "post". ${ }^{41}$ Following the original design, I group firms into "treated" or "control" based on their RPT level in 2004, 2005 and 2006. As can be seen in Table AXII, I do not find significant difference in the change of the key outcome variables between the "treated" group and the "control" group.

\section{Conclusion}

In this paper I use the Indian's mandatory RPT voting rule to shed light on how to mitigate the expropriation of minority shareholders in the presence of business groups with concentrated control rights. My evidence shows that RPT resolutions receive significant higher shareholders dissent compared to other resolutions, which is explained by both the "majority-of-minority" feature of the rule and that shareholder cast against votes more frequently. This implies that the expropriation through RPTs is indeed a primary concern of minority shareholders, and that shareholder voting enables minority shareholders to make a meaningful impact on addressing this concern. Using a difference-in-difference design for identification, I show that the voting rule has a deterrence effect on the level of RPTs, especially on financial transactions. The drop in RPTs for the treated firms (relative to the control firms) is accompanied by an increase in shareholder value and higher institutional holdings.

My results have implication to policy makers and practitioners who interested in pro-

\footnotetext{
${ }^{40}$ The potential preemptive reaction may introduce attenuation bias to the original DID design. However, this concern does not invalidate the qualitative result if the null hypothesis of no effect is rejected.

${ }^{41}$ Since the 2008 financial year ends in March 2008, the potential impact of the financial crisis should be minimal. In March 2008, the level of S\&P 500 index and its Indian equivalent, S\&P BSE 500 index, were comparable to their 2013 levels.
} 
tecting minority shareholders from expropriation. Anecdotes and academic research show that related party transactions can help business groups overcome market frictions, but can also be used to expropriate minority shareholders' wealth. My paper shows that mandatory shareholder voting can serve as a filter to curb the expropriation element from transactions that serve legitimate business purposes. However, to make the voting rule "bite", the voting rights should be primarily given to the minority shareholders, especially in companies where control rights are concentrated. Alleviating the concern of expropriation have a positive effect on shareholder value and make firms more attractive to foreign institutional investors. 
Tables and Figures 

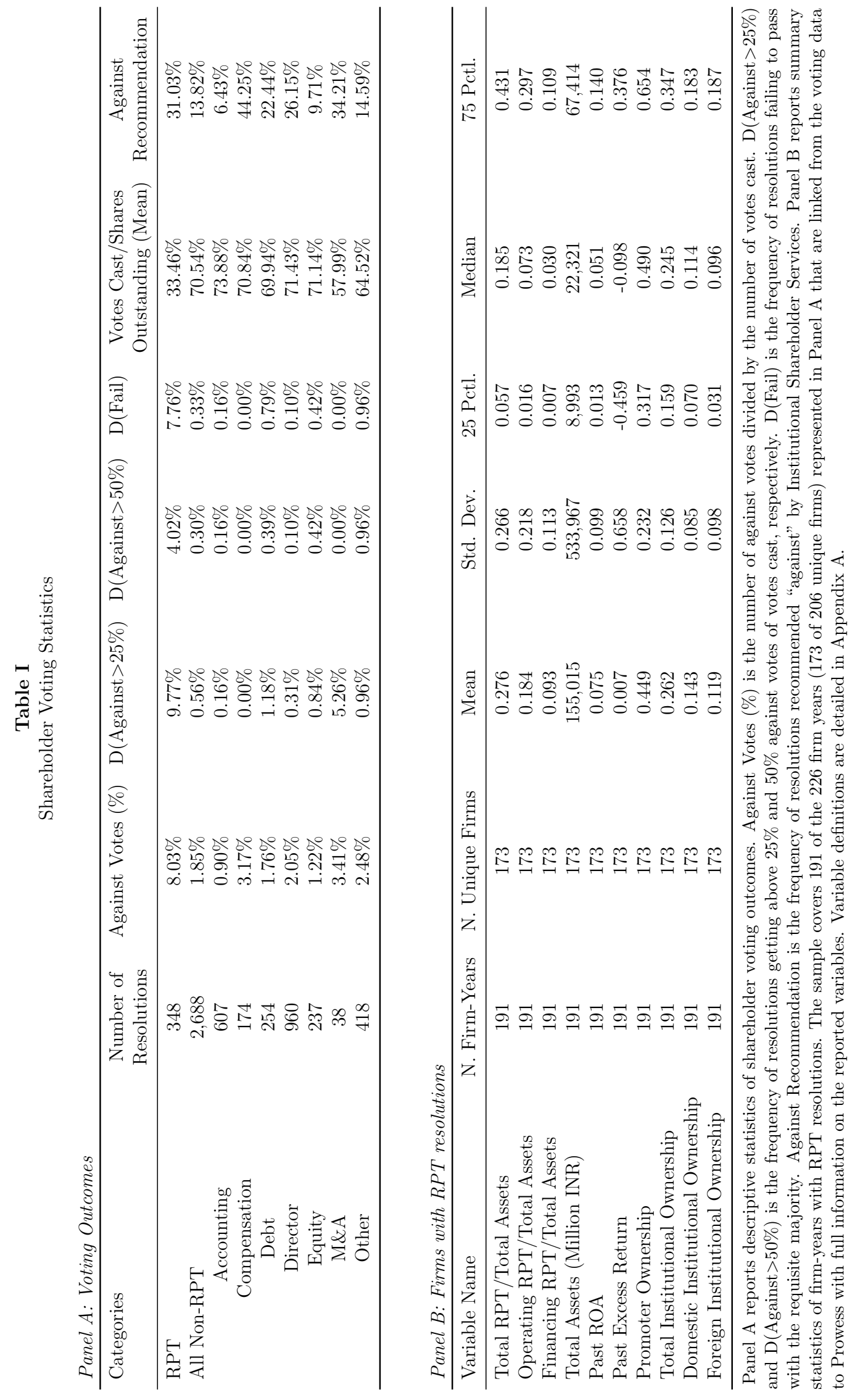
Table II

Determinants of Voting Outcomes and Proxy Recommendations

\begin{tabular}{|c|c|c|c|c|c|c|c|c|}
\hline $\begin{array}{l}\text { Outcome Variable } \\
\text { Regression Model }\end{array}$ & \multicolumn{3}{|c|}{$\begin{array}{l}\text { Against Percent } \\
\text { Linear } \\
\end{array}$} & \multicolumn{3}{|c|}{$\begin{array}{l}\mathrm{D}(\text { Against }>25 \%) \\
\text { Logit }\end{array}$} & \multicolumn{2}{|c|}{$\begin{array}{c}\mathrm{D} \text { (Against Recommendation) } \\
\text { Logit }\end{array}$} \\
\hline Past Total RPT & $\begin{array}{c}(1) \\
0.109^{*} \\
(1.89)\end{array}$ & (2) & (3) & $\begin{array}{c}(4) \\
2.385^{* *} \\
(2.55)\end{array}$ & (5) & (6) & $\begin{array}{c}(7) \\
-0.137 \\
(-0.19)\end{array}$ & (8) \\
\hline Past Operating RPT & & $\begin{array}{l}0.066 \\
(0.83)\end{array}$ & $\begin{array}{l}0.100 \\
(1.37)\end{array}$ & & $\begin{array}{l}0.901 \\
(0.57)\end{array}$ & $\begin{array}{l}1.966 \\
(1.38)\end{array}$ & & $\begin{array}{l}-1.405 \\
(-1.41)\end{array}$ \\
\hline Past Financing RPT & & $\begin{array}{c}0.283^{* *} \\
(2.31)\end{array}$ & $\begin{array}{r}0.201^{*} \\
(1.87)\end{array}$ & & $\begin{array}{c}6.965^{* *} \\
(2.23)\end{array}$ & $\begin{array}{c}6.264^{* *} \\
(2.12)\end{array}$ & & $\begin{array}{r}2.855^{*} \\
(1.82)\end{array}$ \\
\hline Against Recommendation & & & $\begin{array}{c}0.139^{* * *} \\
(4.84)\end{array}$ & & & $\begin{array}{c}1.897^{* * *} \\
(3.33)\end{array}$ & & \\
\hline $\log$ (Total Assets) & $\begin{array}{l}0.002 \\
(0.11)\end{array}$ & $\begin{array}{l}0.002 \\
(0.14)\end{array}$ & $\begin{array}{l}0.008 \\
(0.61)\end{array}$ & $\begin{array}{l}-0.281 \\
(-0.95)\end{array}$ & $\begin{array}{l}-0.295 \\
(-0.96)\end{array}$ & $\begin{array}{l}-0.210 \\
(-0.69)\end{array}$ & $\begin{array}{l}-0.205 \\
(-1.60)\end{array}$ & $\begin{array}{r}-0.201^{*} \\
(-1.68)\end{array}$ \\
\hline Past ROA & $\begin{array}{c}-0.344^{* *} \\
(-2.23)\end{array}$ & $\begin{array}{c}-0.353^{* *} \\
(-2.27)\end{array}$ & $\begin{array}{c}-0.266^{* *} \\
(-2.44)\end{array}$ & $\begin{array}{c}-5.521^{* * * *} \\
(-3.22)\end{array}$ & $\begin{array}{c}-6.368^{* * *} \\
(-3.31)\end{array}$ & $\begin{array}{c}-5.540^{* *} \\
(-2.37)\end{array}$ & $\begin{array}{r}-2.828^{*} \\
(-1.72)\end{array}$ & $\begin{array}{r}-3.175^{*} \\
(-1.91)\end{array}$ \\
\hline Past Excess Return & $\begin{array}{l}-0.010 \\
(-0.53)\end{array}$ & $\begin{array}{l}-0.006 \\
(-0.30)\end{array}$ & $\begin{array}{l}-0.004 \\
(-0.27)\end{array}$ & $\begin{array}{l}-0.212 \\
(-0.60)\end{array}$ & $\begin{array}{l}-0.017 \\
(-0.04)\end{array}$ & $\begin{array}{l}-0.160 \\
(-0.35)\end{array}$ & $\begin{array}{l}-0.164 \\
(-0.52)\end{array}$ & $\begin{array}{l}-0.067 \\
(-0.22)\end{array}$ \\
\hline Promoter Ownership & $\begin{array}{l}0.061 \\
(1.01)\end{array}$ & $\begin{array}{l}0.047 \\
(0.74)\end{array}$ & $\begin{array}{l}0.026 \\
(0.43)\end{array}$ & $\begin{array}{l}2.798^{*} \\
(1.87)\end{array}$ & $\begin{array}{l}2.518 \\
(1.45)\end{array}$ & $\begin{array}{l}2.647 \\
(1.39)\end{array}$ & $\begin{array}{l}1.352^{*} \\
(1.64)\end{array}$ & $\begin{array}{l}1.050 \\
(1.32)\end{array}$ \\
\hline Domestic Inst. Ownership & $\begin{array}{l}-0.028 \\
(-0.21)\end{array}$ & $\begin{array}{l}0.041 \\
(0.28)\end{array}$ & $\begin{array}{l}-0.013 \\
(-0.09)\end{array}$ & $\begin{array}{l}-0.011 \\
(0.00)\end{array}$ & $\begin{array}{l}3.196 \\
(0.81)\end{array}$ & $\begin{array}{l}2.287 \\
(0.52)\end{array}$ & $\begin{array}{l}0.967 \\
(0.50)\end{array}$ & $\begin{array}{l}2.375 \\
(1.15)\end{array}$ \\
\hline Foreign Inst. Ownership & $\begin{array}{c}0.368^{* *} \\
(2.04)\end{array}$ & $\begin{array}{c}0.385^{* *} \\
(2.09)\end{array}$ & $\begin{array}{l}0.270^{*} \\
(1.69)\end{array}$ & $\begin{array}{c}10.042^{* * *} \\
(3.04)\end{array}$ & $\begin{array}{c}11.702^{* *} \\
(2.52)\end{array}$ & $\begin{array}{c}10.253^{* *} \\
(2.20)\end{array}$ & $\begin{array}{c}3.931^{* *} \\
(2.21)\end{array}$ & $\begin{array}{c}4.286^{* *} \\
(2.23)\end{array}$ \\
\hline \# of Observations & 288 & 288 & 288 & 288 & 288 & 288 & 288 & 288 \\
\hline R-squared/Pseudo R-squared & 0.138 & 0.155 & 0.259 & 0.225 & 0.283 & 0.362 & 0.060 & 0.089 \\
\hline
\end{tabular}

This table reports the result from regressions exploring the cross-sectional determinants of RPT resolutions' voting outcomes. The sample contains 288 RPT resolutions in financial year 2015 and 2016. The sample size is smaller than Table I Panel A because the current table only contains observations that are linked from the voting data to Prowess with full information on the reported variables. The dependent variable for column 1, 2, 3 is the percent of "against" votes of votes cast received by the resolution. The dependent variable for column 4,5 and 6 is an indicator denoting that the resolution receives above $25 \%$ against votes. The dependent variable for column 7 and 8 is an indicator denoting an "against" recommendation by the Institutional Shareholder Services. The regression model column 1-3 is a linear model with OLS estimation, whereas the model for column 4-8 is a logit model with maximum-likelihood estimation. Past Total RPT, Past Operating RPT and Past Financing RPT are the one-year lagged total RPT, operating RPT and financing RPT level divided by total assets, respectively. Past ROA and Past Excess Return are the one-year lagged accounting return on assets and excess stock return (raw return minus market return), respectively. Variable definitions are detailed in Appendix A. Standard errors in all models are clustered at firm level. T-statistics are reported in parentheses. *, **, and ${ }^{* * *}$ denote statistically different from zero at $10 \%, 5 \%$, and $1 \%$ significance level in two-tailed $t$ tests, respectively. 
Table III

Summary Statistics for the Difference-in-Difference Sample

Panel A: Pre-Treatment Firm Characteristics

\begin{tabular}{|c|c|c|c|c|c|}
\hline \multirow[t]{2}{*}{ Variable Name } & \multicolumn{2}{|l|}{ Treated } & \multicolumn{2}{|l|}{ Control } & \multirow{2}{*}{$\begin{array}{c}\text { Difference } \\
\text { in Mean }\end{array}$} \\
\hline & N. Firm-Years & Mean & N. Firm-Years & Mean & \\
\hline Total RPT/Total Assets & 1,080 & 0.556 & 3,629 & 0.212 & $0.344^{* * *}$ \\
\hline Material RPT/Total Assets & 1,080 & 0.486 & 3,629 & 0.138 & $0.348^{* * *}$ \\
\hline Non-material RPT/Total Assets & 1,080 & 0.070 & 3,629 & 0.074 & -0.005 \\
\hline Operating RPT/Total Assets & 1,080 & 0.296 & 3,629 & 0.107 & $0.190^{* * *}$ \\
\hline Financing RPT/Total Assets & 1,080 & 0.260 & 3,629 & 0.106 & $0.154^{* * *}$ \\
\hline Number of Related Parties & 1,080 & 8.686 & 3,629 & 6.796 & $1.890^{* * *}$ \\
\hline Number of "Material" Related Parties & 1,080 & 1.754 & 3,629 & 0.425 & $1.329^{* * *}$ \\
\hline Total Assets (Million INR) & 1,080 & 29,816 & 3,629 & 21,253 & $8,563^{*}$ \\
\hline Total Assets (log) & 1,080 & 7.734 & 3,629 & 7.546 & $0.188^{* *}$ \\
\hline $\mathrm{ROA}$ & 1,080 & 0.024 & 3,629 & 0.030 & $-0.006^{*}$ \\
\hline Past Excess Return & 1,080 & -0.010 & 3,629 & -0.019 & 0.009 \\
\hline leverage & 1,080 & 0.339 & 3,629 & 0.303 & $0.037^{* * *}$ \\
\hline Promoter ownership & 1,065 & 0.542 & 3,584 & 0.512 & $0.029^{* * *}$ \\
\hline Total Institutional Ownership & 1,065 & 0.154 & 3,584 & 0.160 & -0.006 \\
\hline Domestic Institutional Ownership & 1,065 & 0.115 & 3,584 & 0.125 & $-0.010 * * *$ \\
\hline Foreign Institutional Ownership & 1,065 & 0.039 & 3,584 & 0.035 & $0.005^{*}$ \\
\hline
\end{tabular}

Panel B: Change in Outcome Variables From Pre- to Post-Treatement Period

\begin{tabular}{lccccc}
\hline Variable Name & Treated & \multicolumn{2}{c}{ Control } & \multicolumn{2}{c}{ Univariate } \\
& Pre & Post & Pre & Post & DID \\
\hline Total RPT/Total Assets & 0.556 & 0.445 & 0.212 & 0.207 & -0.116 \\
Material RPT/Total Assets & 0.486 & 0.371 & 0.138 & 0.143 & -0.110 \\
Non-material RPT/Total Assets & 0.070 & 0.074 & 0.074 & 0.064 & -0.006 \\
Operating RPT/Total Assets & 0.296 & 0.242 & 0.107 & 0.099 & -0.061 \\
Financing RPT/Total Assets & 0.260 & 0.204 & 0.106 & 0.108 & -0.054 \\
Total Institutional Ownership & 0.154 & 0.165 & 0.160 & 0.155 & 0.006 \\
Domestic Institutional Ownership & 0.115 & 0.113 & 0.126 & 0.119 & -0.009 \\
Foreign Institutional Ownership & 0.039 & 0.052 & 0.035 & 0.036 & 0.014 \\
\hline
\end{tabular}

Panel A reports the mean firm characteristics for the treated group and the control group. *, **, and *** denote the mean between treated and control are statistically different from zero at $10 \%, 5 \%$, and $1 \%$ significance level in two-tailed $t$ tests, respectively. Panel B presents the mean outcome variables for treated and control groups, before and after the adoption of the RPT voting rule. The column "Univariate DID" reports the result of [(column 2 column 1) - (column 4 - column 3)]. Variable definitions are detailed in Appendix A. 
Table IV

The Effect of RPT Voting on RPT level: Baseline Regression Results

\begin{tabular}{|c|c|c|c|c|c|c|}
\hline \multirow{2}{*}{ Outcome Variable } & \multicolumn{2}{|c|}{ Total RPT } & \multicolumn{2}{|c|}{ Material RPT } & \multicolumn{2}{|c|}{ Non-material RPT } \\
\hline & (1) & (2) & (3) & (4) & (5) & (6) \\
\hline Treated $\times$ Post & $\begin{array}{c}-0.079 * * * \\
(-3.39)\end{array}$ & $\begin{array}{c}-0.076^{* * *} \\
(-3.13)\end{array}$ & $\begin{array}{c}-0.106 * * * \\
(-4.74)\end{array}$ & $\begin{array}{c}-0.097 * * * \\
(-4.14)\end{array}$ & $\begin{array}{c}0.015^{* * *} \\
(3.11)\end{array}$ & $\begin{array}{c}0.013^{* *} \\
(2.40)\end{array}$ \\
\hline Log(Total Assets) & $\begin{array}{l}0.011 \\
(0.23)\end{array}$ & $\begin{array}{c}0.078^{* *} \\
(1.96)\end{array}$ & $\begin{array}{l}0.023 \\
(0.53)\end{array}$ & $\begin{array}{l}0.078^{*} \\
(1.84)\end{array}$ & $\begin{array}{l}0.004 \\
(0.99)\end{array}$ & $\begin{array}{l}0.007 \\
(1.24)\end{array}$ \\
\hline Leverage & $\begin{array}{c}0.202 * * * \\
(2.81)\end{array}$ & $\begin{array}{c}0.192^{* *} \\
(1.97)\end{array}$ & $\begin{array}{c}0.211^{* * *} \\
(3.09)\end{array}$ & $\begin{array}{c}0.223^{* *} \\
(2.35)\end{array}$ & $\begin{array}{c}-0.025^{* * *} \\
(-3.31)\end{array}$ & $\begin{array}{c}-0.029^{* *} \\
(-2.20)\end{array}$ \\
\hline Past Excess Return & $\begin{array}{c}0.013^{*} \\
(1.74)\end{array}$ & $\begin{array}{l}0.012^{*} \\
(1.91)\end{array}$ & $\begin{array}{l}0.008 \\
(1.34)\end{array}$ & $\begin{array}{l}0.007 \\
(1.16)\end{array}$ & $\begin{array}{c}0.004^{* *} \\
(2.53)\end{array}$ & $\begin{array}{c}0.004^{* *} \\
(2.26)\end{array}$ \\
\hline Auditor Switch & & $\begin{array}{l}0.021 \\
(1.38)\end{array}$ & & $\begin{array}{l}0.000 \\
(0.04)\end{array}$ & & $\begin{array}{l}0.008 \\
(1.61)\end{array}$ \\
\hline Log(CEO Pay $)$ & & $\begin{array}{l}0.003 \\
(0.55)\end{array}$ & & $\begin{array}{l}0.002 \\
(0.41)\end{array}$ & & $\begin{array}{c}0.004^{* * *} \\
(2.59)\end{array}$ \\
\hline Pct. New Director & & $\begin{array}{c}0.112^{* * *} \\
(2.74)\end{array}$ & & $\begin{array}{c}0.090^{* *} \\
(2.39)\end{array}$ & & $\begin{array}{l}0.015 \\
(1.56)\end{array}$ \\
\hline Board Independence & & $\begin{array}{l}-0.051 \\
(-1.00)\end{array}$ & & $\begin{array}{l}-0.055 \\
(-1.14)\end{array}$ & & $\begin{array}{l}-0.013 \\
(-0.96)\end{array}$ \\
\hline Audit. Com. Independence & & $\begin{array}{l}-0.003 \\
(-0.09)\end{array}$ & & $\begin{array}{l}-0.007 \\
(-0.20)\end{array}$ & & $\begin{array}{l}0.004 \\
(0.37)\end{array}$ \\
\hline CSR Expenditure & & $\begin{array}{l}0.727 \\
(0.11)\end{array}$ & & $\begin{array}{c}-11.992^{*} \\
(-1.89)\end{array}$ & & $\begin{array}{c}7.397^{* * *} \\
(2.71)\end{array}$ \\
\hline Number of Observations & 7,743 & 5,921 & 7,743 & 5,921 & 7,743 & 5,921 \\
\hline Number of Firms & 1,716 & 1,583 & 1,716 & 1,583 & 1,716 & 1,583 \\
\hline Fixed Effects & Firm, Year & Firm, Year & Firm, Year & Firm, Year & Firm, Year & Firm, Year \\
\hline Basic Control & Yes & Yes & Yes & Yes & Yes & Yes \\
\hline Additional Control & No & Yes & No & Yes & No & Yes \\
\hline Adj. R-squared & 0.567 & 0.676 & 0.540 & 0.646 & 0.518 & 0.560 \\
\hline
\end{tabular}

This table reports the results from the difference-in-difference regressions relating the mandatory RPT voting rule to firms' RPT levels. The dependent variable is Total RPT for column 1 and 2, Material RPT for column 3 and 4, and Non-material RPT for column 5 and 6 . In column 1, 3 and 5, the full sample is used for estimation; in column 2, 4 and 6 , the subsample with additional control variables is used. Variable definitions are detailed in Appendix A. All specifications include firm fixed effects and year fixed effects. Standard errors are clustered by firm. T-statistics are reported in parentheses. *, **, and $* * *$ denote statistically different from zero at $10 \%, 5 \%$, and $1 \%$ significance level in two-tailed $t$ tests, respectively. 
Table V

The Effect of RPT Voting on RPT level: Operating vs. Financing

\begin{tabular}{lcccc}
\hline Outcome Variable & \multicolumn{2}{c}{ Operating RPT } & \multicolumn{2}{c}{ Financing RPT } \\
\hline & $(1)$ & $(2)$ & $(3)$ & $(4)$ \\
Treated $\times$ Post & -0.022 & -0.020 & $-0.051^{* * *}$ & $-0.040^{* * *}$ \\
& $(-1.64)$ & $(-1.48)$ & $(-3.77)$ & $(-2.75)$ \\
Number of Observations & 7,743 & 5,921 & & \\
Number of Firms & 1,716 & 1,583 & 1,743 & 5,921 \\
Fixed Effects & Firm, Year & Firm, Year & Firm, Year & Firm, Year \\
Basic Control & Yes & Yes & Yes & Yes \\
Additional Control & No & Yes & No & Yes \\
Adj. R-squared & 0.629 & 0.756 & 0.529 & 0.564 \\
\hline
\end{tabular}

This table reports the results from the difference-in-difference regressions relating the mandatory RPT voting rule to Operating RPT and FInancing RPT. The dependent variable is Operating RPT for column 1 and 2 and Financing RPT for column 3 and 4 . In column 1 and 3, the full sample is used for estimation; in column 2 and 4 the subsample with additional control variables is used. Variable definitions are detailed in Appendix A. All specifications include firm fixed effects and year fixed effects. Standard errors are clustered by firm. T-statistics are reported in parentheses. *, **, and *** denote statistically different from zero at $10 \%, 5 \%$, and $1 \%$ significance level in two-tailed $t$ tests, respectively. 
Table VI

Market Response to Events Related to the RPT Voting Rule

\begin{tabular}{lccccc}
\hline \multicolumn{2}{l}{ Outcome Variable: Three Day Cumulative Excess Return } & $(-1,0,+1)$ & & \\
& Event 1 & Event 2 & Event 3 & Event 4 & Cumulative \\
\hline \multirow{3}{*}{ Treated } & $(1)$ & $(2)$ & $(3)$ & $(4)$ & $(5)$ \\
& $\mathbf{0 . 0 1 0 * *}$ & $\mathbf{0 . 0 1 9 * * *}$ & $\mathbf{0 . 0 0 4}$ & $\mathbf{0 . 0 0 3}$ & $\mathbf{0 . 0 3 8 * * *}$ \\
Log(Total Assets) & $\mathbf{( 2 . 2 3 )}$ & $\mathbf{( 2 . 8 9 )}$ & $\mathbf{( 0 . 9 2 )}$ & $\mathbf{( 0 . 6 9 )}$ & $\mathbf{( 3 . 3 8 )}$ \\
& 0.001 & $0.007^{* * *}$ & 0.001 & -0.001 & $0.009^{* * *}$ \\
Book-to-Market & $(1.16)$ & $(4.92)$ & $(0.85)$ & $(-0.64)$ & $(3.29)$ \\
& 0.000 & 0.002 & $-0.004^{* * *}$ & 0.000 & -0.002 \\
Audit Switch (Past 3 years) & $(0.49)$ & $(1.56)$ & $(-4.11)$ & $(-0.12)$ & $(-0.77)$ \\
& 0.005 & -0.004 & -0.003 & 0.002 & -0.001 \\
Log(CEO pay) & $(1.33)$ & $(-0.78)$ & $(-0.67)$ & $(0.61)$ & $(-0.08)$ \\
Board Independence & 0.000 & 0.000 & 0.000 & 0.000 & 0.000 \\
CSR Coverage & $(-0.71)$ & $(0.42)$ & $(0.25)$ & $(0.79)$ & $(0.37)$ \\
& 0.011 & -0.001 & 0.003 & 0.013 & 0.030 \\
& $(0.72)$ & $(-0.07)$ & $(0.24)$ & $(0.91)$ & $(0.81)$ \\
Number of firms & 0.003 & 0.004 & -0.007 & 0.004 & 0.005 \\
Adj. R-squared & $(0.73)$ & $(0.64)$ & $(-1.42)$ & $(0.74)$ & $(0.40)$ \\
\hline
\end{tabular}

This table reports the results of estimating the stock market response to the events that signals the passage of the RPT voting rule. From column 1 to 4, the dependent variable is 3 day cumulative excess return. In column 5, the outcome variable is the cumulative excess return from all 4 events (i.e. 12 event days). Variable definitions are detailed in Appendix A. Standard errors are Huber-White robust standard errors. T-statistics are reported in parentheses. *, **, and ${ }^{* * *}$ denote statistically different from zero at $10 \%, 5 \%$, and $1 \%$ significance level in two-tailed $t$ tests, respectively. 
Table VII

The Effect of RPT Voting on the Association Between RPT and Profitability

\begin{tabular}{|c|c|c|c|c|c|c|}
\hline \multicolumn{7}{|c|}{ Outcome Variable: Return on Assets } \\
\hline & (1) & $(2)$ & (3) & (4) & $(5)$ & (6) \\
\hline \multirow[t]{2}{*}{$\mathrm{RPT}$} & 0.006 & $0.018^{*}$ & 0.004 & 0.012 & $0.014^{*}$ & 0.029 \\
\hline & $(0.69)$ & $(1.77)$ & $(0.28)$ & $(1.14)$ & $(1.88)$ & $(1.42)$ \\
\hline \multirow[t]{2}{*}{$\mathrm{RPT} \times$ Treated } & 0.011 & 0.001 & 0.013 & 0.000 & -0.009 & -0.027 \\
\hline & $(0.68)$ & $(0.07)$ & $(0.43)$ & $(-0.02)$ & $(-0.67)$ & $(-1.18)$ \\
\hline \multirow[t]{2}{*}{$\mathrm{RPT} \times$ Post } & -0.005 & -0.010 & -0.004 & -0.015 & -0.008 & -0.016 \\
\hline & $(-0.58)$ & $(-1.14)$ & $(-0.42)$ & $(-1.41)$ & $(-0.54)$ & $(-0.78)$ \\
\hline \multirow[t]{2}{*}{ RPT $\times$ Treated $\times$ Post } & $0.029 * *$ & $0.027^{*}$ & 0.018 & 0.018 & $0.064^{* * *}$ & $0.080^{* *}$ \\
\hline & $(2.04)$ & $(1.91)$ & $(1.05)$ & $(1.20)$ & $(2.74)$ & $(2.42)$ \\
\hline \multirow[t]{2}{*}{ Treated $\times$ Post } & -0.009 & -0.006 & -0.003 & 0.000 & $-0.010^{*}$ & $-0.010^{*}$ \\
\hline & $(-1.43)$ & $(-1.03)$ & $(-0.43)$ & $(-0.02)$ & $(-1.88)$ & $(-1.70)$ \\
\hline Number of Observations & 7,743 & 5,921 & 7,743 & 5,921 & 7,743 & 5,921 \\
\hline Number of Firms & 1,716 & 1,583 & 1,716 & 1,583 & 1,716 & 1,583 \\
\hline Fixed Effects & Firm, Year & Firm, Year & Firm, Year & Firm, Year & Firm, Year & Firm, Year \\
\hline Basic Control & Yes & Yes & Yes & Yes & Yes & Yes \\
\hline Additional Control & No & Yes & No & Yes & No & Yes \\
\hline Adj. R-squared & 0.559 & 0.633 & 0.557 & 0.631 & 0.560 & 0.634 \\
\hline
\end{tabular}

This table reports the results from the difference-in-difference regressions relating the mandatory RPT voting rule to the association between RPT and firm profitability. The dependent variable is Return on Assets (ROA) for all columns. The independent variable RPT is Total RPT for column 1 and 2, Operating RPT for column 3 and 4 , and Financing RPT for column 5 and 6. In column 1, 3 and 5, the full sample is used for estimation; in column 2, 4 and 6 , the subsample with additional control variables is used. Variable definitions are detailed in Appendix A. All specifications include firm fixed effects and year fixed effects. Standard errors are clustered by firm. T-statistics are reported in parentheses. *, **, and *** denote statistically different from zero at $10 \%, 5 \%$, and $1 \%$ significance level in two-tailed $t$ tests, respectively. 
Table VIII

The Effect of RPT Voting on Institutional Ownership

\begin{tabular}{|c|c|c|c|c|c|c|}
\hline \multirow[t]{2}{*}{ Outcome Variable } & \multicolumn{2}{|c|}{ Total Inst. Ownership } & \multicolumn{2}{|c|}{ Domestic Inst. Ownership } & \multicolumn{2}{|c|}{ Foreign Inst. Ownership } \\
\hline & (1) & $(2)$ & $(3)$ & (4) & $(5)$ & (6) \\
\hline \multirow[t]{2}{*}{ Treated $\times$ Post } & $0.014^{* * *}$ & $0.013 * * *$ & 0.005 & 0.002 & $0.008 * * *$ & $0.010 * * *$ \\
\hline & $(3.31)$ & $(2.59)$ & $(1.49)$ & $(0.54)$ & $(3.57)$ & $(3.80)$ \\
\hline \multirow[t]{2}{*}{ Log(Total Assets) } & $0.029 * * *$ & $0.018 * * *$ & $0.016^{* * *}$ & 0.001 & $0.013^{* * * *}$ & $0.017^{* * *}$ \\
\hline & $(4.99)$ & $(3.72)$ & $(2.86)$ & $(0.27)$ & $(6.40)$ & $(5.95)$ \\
\hline \multirow[t]{2}{*}{ Leverage } & -0.011 & $-0.015^{*}$ & -0.003 & 0.000 & $-0.009 * * *$ & $-0.015^{* * *}$ \\
\hline & $(-1.55)$ & $(-1.65)$ & $(-0.40)$ & $(-0.05)$ & $(-2.70)$ & $(-2.59)$ \\
\hline \multirow[t]{2}{*}{ Past Excess Return } & $0.003^{* *}$ & $0.004^{* *}$ & 0.000 & 0.001 & $0.003^{* * *}$ & $0.003^{* * *}$ \\
\hline & $(2.36)$ & $(2.48)$ & $(0.19)$ & $(0.60)$ & $(4.37)$ & $(3.33)$ \\
\hline \multirow[t]{2}{*}{ Auditor Switch } & & $0.006^{*}$ & & 0.003 & & $0.003^{*}$ \\
\hline & & $(1.72)$ & & $(0.81)$ & & $(1.76)$ \\
\hline \multirow[t]{2}{*}{ Log(CEO Pay) } & & 0.002 & & 0.000 & & $0.002^{* *}$ \\
\hline & & $(1.43)$ & & $(0.04)$ & & $(2.23)$ \\
\hline \multirow[t]{2}{*}{ Pct. New Director } & & -0.009 & & -0.001 & & $-0.007^{*}$ \\
\hline & & $(-1.16)$ & & $(-0.20)$ & & $(-1.95)$ \\
\hline \multirow{2}{*}{ Board Independence } & & -0.007 & & -0.005 & & -0.002 \\
\hline & & $(-0.52)$ & & $(-0.40)$ & & $(-0.30)$ \\
\hline \multirow[t]{2}{*}{ Auditing Com. Independence } & & 0.006 & & 0.011 & & -0.005 \\
\hline & & $(0.64)$ & & $(1.32)$ & & $(-1.06)$ \\
\hline \multirow[t]{2}{*}{ CSR Expenditure } & & $7.152^{* * *}$ & & 1.729 & & $5.423^{* * *}$ \\
\hline & & $(4.04)$ & & $(1.03)$ & & $(4.55)$ \\
\hline \# of Observations & 7,655 & 5,896 & 7,655 & 5,896 & 7,655 & 5,896 \\
\hline \# of Firms & 1,716 & 1,578 & 1,716 & 1,578 & 1,716 & 1,578 \\
\hline Fixed Effects & Firm, Year & Firm, Year & Firm, Year & Firm, Year & Firm, Year & Firm, Year \\
\hline Basic Control & Yes & Yes & Yes & Yes & Yes & Yes \\
\hline Additional Control & No & Yes & No & Yes & No & Yes \\
\hline Adj. R-squared & 0.841 & 0.852 & 0.771 & 0.773 & 0.878 & 0.887 \\
\hline
\end{tabular}

This table reports the results from the difference-in-difference regressions relating the mandatory RPT voting rule to institutional ownership. The dependent variable is total institutional ownership for column 1 and 2, domestic institutional ownership for column 3 and 4, and foreign institutional ownership for column 5 and 6 . In column 1, 3 and 5 , the full sample is used for estimation; in column 2, 4 and 6, the subsample with additional control variables is used. Variable definitions are detailed in Appendix A. All specifications include firm fixed effects and year fixed effects. Standard errors are clustered by firm. T-statistics are reported in parentheses. ${ }^{*},{ }^{* *}$, and ${ }^{* * *}$ denote statistically different from zero at $10 \%, 5 \%$, and $1 \%$ significance level in two-tailed $t$ tests, respectively. 
Figure I. Differential Trends of RPTs around Voting Rule

This figure plots the difference-in-difference estimates for the effect of RPT voting on RPT levels, where the point estimate is allowed to vary by year. The solid points indicate pointestimate, and the dashed lines represent 95\% confidence interval. Financial year 2014, the year immediately before the voting rule's adoption, serves as the reference point.

Total RPT

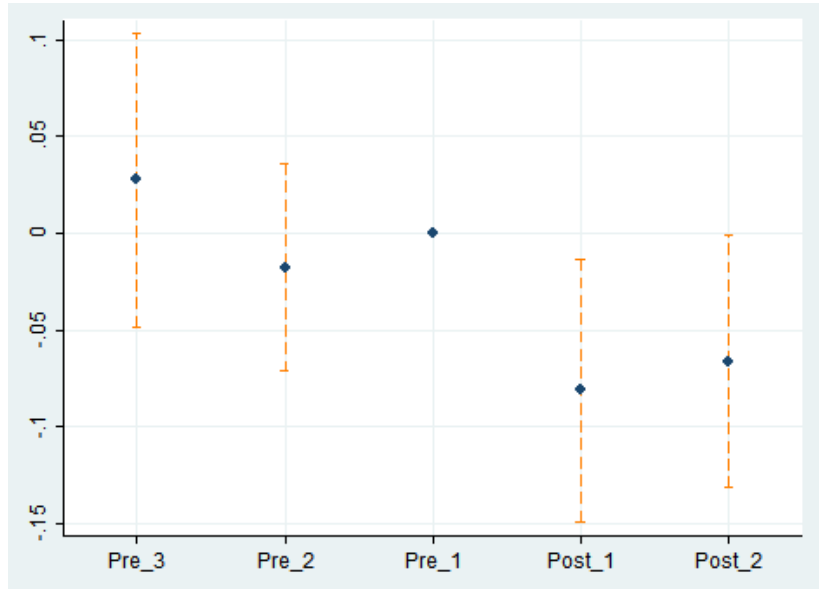

Operating RPT

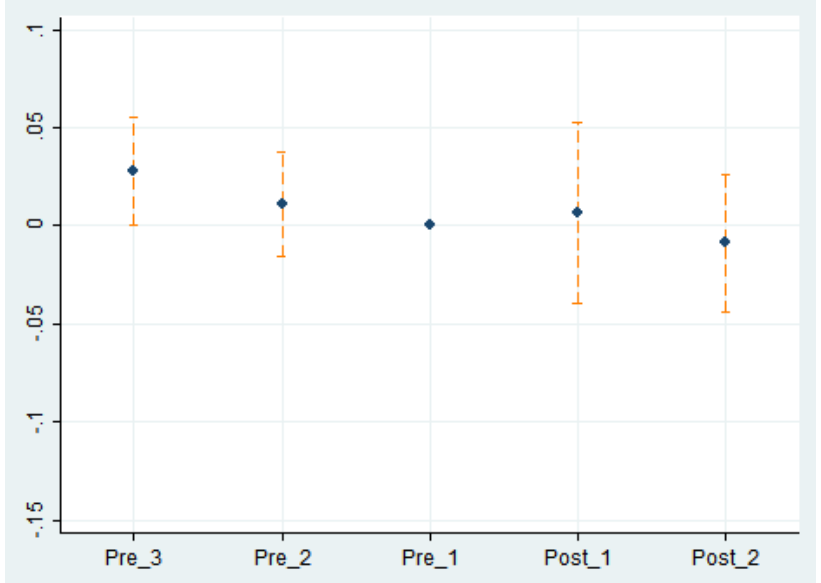

Financing RPT

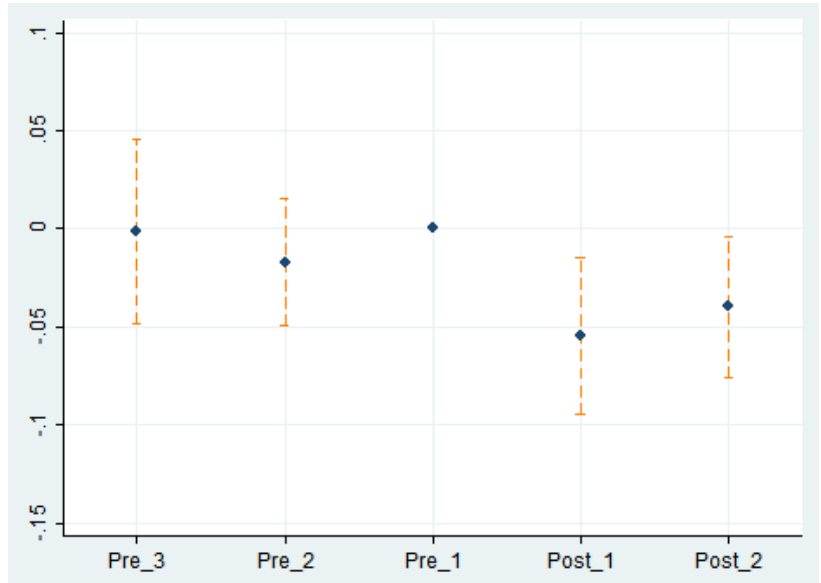




\section{References}

Aggarwal, Reena, Isil Erel, Miguel Ferreira, and Pedro Matos, 2011, Does governance travel around the world? Evidence from institutional investors, Journal of Financial Economics 100, 154-181.

Aghion, Philippe, and Jean Tirole, 1997, Formal and real authority in organizations, Journal of Political Economy 105, 1-29.

Appel, Ian R, Todd A Gormley, and Donald B Keim, 2016, Passive investors, not passive owners, Journal of Financial Economics 121, 111-141.

Armstrong, Chris, Stephen Glaeser, and Sterling Huang, 2017, Corporate hedging and the design of incentive-compensation contracts .

Atanasov, Vladimir, Bernard Black, et al., 2016, Shock-based causal inference in corporate finance and accounting research, Critical Finance Review 5, 207-304.

Atanasov, Vladimir, Bernard Black, Conrad Ciccotello, and Stanley Gyoshev, 2010, How does law affect finance? an examination of equity tunneling in bulgaria, Journal of Financial Economics $96,155-173$.

Atanasov, Vladimir, Bernard Black, and Conrad S Ciccotello, 2011, Law and tunneling, Journal of Corporation Law 37, 1.

Bae, Kee-Hong, Jun-Koo Kang, and Jin-Mo Kim, 2002, Tunneling or value added? Evidence from mergers by korean business groups, The Journal of Finance 57, 2695-2740.

Bertrand, Marianne, Paras Mehta, and Sendhil Mullainathan, 2002, Ferreting out tunneling: An application to Indian business groups, The Quarterly Journal of Economics 117, 121-148.

Black, Bernard S, 1990, Shareholder passivity reexamined, Michigan Law Review 89, 520-608.

Black, Bernard S, Woochan Kim, Hasung Jang, and Kyung-Suh Park, 2015, How corporate governance affect firm value? Evidence on a self-dealing channel from a natural experiment in korea, Journal of Banking \& Finance 51, 131-150.

Boone, Audra L, and Joshua T White, 2015, The effect of institutional ownership on firm transparency and information production, Journal of Financial Economics 117, 508-533.

Bugeja, Martin, Raymond da Silva Rosa, Yaowen Shan, Terry S Walter, and David Yermack, 2016, Life after a shareholder pay'strike': Consequences for asx-listed firms, Working Paper .

CFA Institute, 2009, Related-party transactions: Cautionary tales for investors in Asia .

Cheung, Yan-Leung, P Raghavendra Rau, and Aris Stouraitis, 2006, Tunneling, propping, and expropriation: evidence from connected party transactions in Hong Kong, Journal of Financial Economics 82, 343-386.

Cox, James D, Fabrizio Ferri, Colleen Honigsberg, and Randall S Thomas, 2016, Quieting the shareholders' voice: Empirical evidence of pervasive bundling in proxy solicitations, Southern California Law Review 89. 
Cuñat, Vicente, Mireia Gine, and Maria Guadalupe, 2012, The vote is cast: The effect of corporate governance on shareholder value, The Journal of Finance 67, 1943-1977.

Djankov, Simeon, Rafael La Porta, Florencio Lopez-de Silanes, and Andrei Shleifer, 2008, The law and economics of self-dealing, Journal of Financial Economics 88, 430-465.

Enriques, Luca, 2015, Related party transactions: Policy options and real-world challenges (with a critique of the european commission proposal), European Business Organization Law Review $16,1-37$.

Ertimur, Yonca, Fabrizio Ferri, and David Oesch, 2013, Shareholder votes and proxy advisors: Evidence from say on pay, Journal of Accounting Research 51, 951-996.

Ferreira, Miguel A, and Pedro Matos, 2008, The colors of investors money: The role of institutional investors around the world, Journal of Financial Economics 88, 499-533.

Ferri, Fabrizio, and Nan Li, 2017, Does option-based compensation affect payout policy? Evidence from FAS123R .

Ferri, Fabrizio, and David A Maber, 2013, Say on pay votes and CEO compensation: Evidence from the UK, Review of Finance 17, 527-563.

Fried, Jesse, Ehud Kamar, and Yishay Yafeh, 2018, The effect of minority veto rights on controller tunneling, Technical report.

Giannetti, Mariassunta, and Andrei Simonov, 2006, Which investors fear expropriation? Evidence from investors' portfolio choices, The Journal of Finance 61, 1507-1547.

Gillan, Stuart L, and Laura T Starks, 2000, Corporate governance proposals and shareholder activism: The role of institutional investors, Journal of Financial Economics 57, 275-305.

Gopalan, Radhakrishnan, Vikram Nanda, and Amit Seru, 2007, Affiliated firms and financial support: Evidence from Indian business groups, Journal of Financial Economics 86, 759-795.

Hainmueller, Jens, 2012, Entropy balancing for causal effects: A multivariate reweighting method to produce balanced samples in observational studies, Political Analysis 20, 25-46.

Iliev, Peter, Karl V Lins, Darius P Miller, and Lukas Roth, 2015, Shareholder voting and corporate governance around the world, The Review of Financial Studies 28, 2167-2202.

Jian, Ming, and T.J. Wong, 2010, Propping through related party transactions, Review of Accounting Studies 15, 70-105.

Jiang, Guohua, Charles MC Lee, and Heng Yue, 2010, Tunneling through intercorporate loans: The China experience, Journal of Financial Economics 98, 1-20.

Johnson, Simon, Peter Boone, Alasdair Breach, and Eric Friedman, 2000, Corporate governance in the Asian financial crisis, Journal of Financial Economics 58, 141-186.

Khanna, Tarun, and Krishna Palepu, 2000, Is group affiliation profitable in emerging markets? An analysis of diversified Indian business groups, The Journal of Finance 55, 867-891. 
Khanna, Tarun, and Yishay Yafeh, 2007, Business groups in emerging markets: Paragons or parasites?, Journal of Economic literature 45, 331-372.

Kho, Bong-Chan, René M Stulz, and Francis E Warnock, 2009, Financial globalization, governance, and the evolution of the home bias, Journal of Accounting Research 47, 597-635.

Kohlbeck, Mark, and Brian W Mayhew, 2010, Valuation of firms that disclose related party transactions, Journal of Accounting and Public Policy 29, 115-137.

Kohlbeck, Mark, and Brian W Mayhew, 2017, Are related party transactions red flags?, Contemporary Accounting Research 34, 900-928.

La Porta, Rafael, Florencio Lopez-de Silanes, and Andrei Shleifer, 1999, Corporate ownership around the world, The Journal of Finance 54, 471-517.

La Porta, Rafael, Florencio Lopez-de Silanes, Andrei Shleifer, and Robert Vishny, 2002, Investor protection and corporate valuation, The Journal of Finance 57, 1147-1170.

Larcker, David F, Allan L McCall, and Gaizka Ormazabal, 2015, Outsourcing shareholder voting to proxy advisory firms, The Journal of Law and Economics 58, 173-204.

Leuz, Christian, Karl V Lins, and Francis E Warnock, 2008, Do foreigners invest less in poorly governed firms?, The Review of Financial Studies 22, 3245-3285.

Li, Tao, 2016, Outsourcing corporate governance: conflicts of interest within the proxy advisory industry, Management Science .

Lu, Ross, 2017, Economic consequences of control-procedure disclosure of related-party transactions: Evidence from the 2006 SEC regulation, Working Paper .

Manchiraju, Hariom, and Shivaram Rajgopal, 2017, Does corporate social responsibility (CSR) create shareholder value? Evidence from the Indian Companies Act 2013, Journal of Accounting Research .

McCahery, Joseph A, Zacharias Sautner, and Laura T Starks, 2016, Behind the scenes: The corporate governance preferences of institutional investors, The Journal of Finance 71, 2905-2932.

OECD, 2009, Guide on fighting abusive related party transactions in Asia .

OECD, 2012, Related party transactions and minority shareholder rights .

Rana, Preetika, 2016, Vijay Mallyas severance payment from diageo halted by Indian tribunal, The Wall Street Journal. Retrieved from www.wsj.com.

Ryngaert, Michael, and Shawn Thomas, 2012, Not all related party transactions (rpts) are the same: Ex ante versus ex post rpts, Journal of Accounting Research 50, 845-882.

Shleifer, Andrei, and Daniel Wolfenzon, 2002, Investor protection and equity markets, Journal of Financial Economics 66, 3-27.

Stacey, Daniel, 2017, 'King of Good Times' gives Diageo a hangover, The Wall Street Journal. Retrieved from www.wsj.com. 


\title{
Appendix A: Variable Definitions
}

\author{
RPT Variables
}

Total RPT: The sum of all related party transactions (excluding director/manager compensation) with all related parties carried out during the financial year, divided by lagged total assets. The specific types of transactions included are described in the definitions of Operating RPT and Financing RPT, which are the two components of Total RPT.

Operating RPT: The sum of operating related party transactions (excluding director/manager compensation) with all related parties carried out during the financial year, divided by lagged total assets. The following items are labeled as operating: income from sale of goods and services, rent income, other operating income, payment for raw material and finished goods, energy expense, marketing expense, processing expense, rent expense, royalty expense, reimbursement of expenses to/by related parties, other operating expenses, other transactions.

Financing RPT: The sum of financing related party transactions with all related parties carried out during the financial year, divided by lagged total assets. The following items are labeled as financing: loans and guarantees given during the year, loans and guarantees taken during the year, purchase/sale of fixed assets, purchase/sale of investments, capital issued during the year, interest payment, interest income, dividend payment, dividend income.

Material RPT: The sum of all related party transactions (excluding director/manager compensation) with the "material" related parties carried out during the financial year, divided by lagged total assets. For firm $i$ in financial year $t$, a related party of firm $i$ is classified as "material" if firm $i$ 's total transaction amount with the party during year $t$ exceeds $10 \%$ of firm $i$ 's most recent consolidated revenue. If firm $i$ does not have a "material" related party during financial year $t$, Material RPT equals 0.

Non-material RPT: Total RPT minus material RPT.

\section{Equity Ownership Variables}

Promotor Ownership: The percentage of shares held by individuals and entities classified as promoters. A company's promoter(s) is legally defined as an individual or entity that control the company. One company can have multiple promoters.

Total Institutional Ownership: The percentage of shares held by all non-promoter institutional investors, including mutual funds, banks, financial institutions, insurance companies, venture capitals, central and state governments, and foreign institutions.

Domestic Institutional Ownership: The percentage of shares held by non-promoter Indian institutional investors.

Foreign Institutional Ownership: The percentage of shares held by non-promoter foreign institutional investors.

\section{Shareholder Voting Variables}

Against Votes (\%): The number of against votes received by a resolution divided by the total number of votes cast on the resolution.

D(Against $>\mathbf{2 5 \%}$ (50\%)): A dummy variable that equals one if the number of against votes received by a resolution is greater than $25 \%$ (50\%) of the votes cast on the resolution.

Against Recommendation: A dummy variable that equals one if ISS recommend "against" on a resolution.

Votes Cast/Shares Outstanding: The number of votes cast on a resolution divided by the number of shares outstanding. 
Other Firm Characteristics

Log(Total Assets): The natural logarithm of the book value of total assets in millions of INR. Leverage: Total borrowings divided by total assets.

Return on Assets (ROA): Total profits before tax divided by lagged total assets. "Past ROA" represents one-year lagged ROA.

Excess Return: Raw return minus the valued weighted average return of the Prowess stock return universe. In the event study, Excess Return is measured at trading day level. In voting regression and DID regressions, Excess Return is measured at annual level. "Past Excess Return" is one-year lagged annual Excess Return.

Audit Switch: A dummy variable that equals 1 if the firm switches auditor in the year and 0 otherwise.

Audit Switch (Past 3 Years): A dummy variable that equals 1 if the firm has switched auditor in the past 3 years prior to the event and 0 otherwise.

Log(CEO pay): The natural logarithm of CEO (or top manager)'s total pay. If a CEO (or top manager) cannot be identified, the total pay of the highest paid director or manager is used.

Percentage of New Directors: The number of newly appointed directors in the year divided by the number of directors on board.

Board Independence: The number of independent directors divided by the total number of directors. Director independence is classified by CMIE (the data vendor) based on company disclosures and CMIE's own information.

Audit Committee Independence: The number of independent directors on the audit committee divided by the number of audit committee members.

CSR Expenditure: CSR expenditure divided by lagged total assets.

CSR Coverage: A dummy variable that takes value of 1 if the firm is affected under the mandatory CSR expensing provision of the 2013 Act. 


\section{Appendix B: Research Design Illustration}

The first example illustrates how material RPT are calculated for firm A and B for financial year $t$. Each firm has three related parties and three possible types of transactions. The unit of currency is INR million. Both firms have revenue INR 100 million in the past financial year. If the sum of transactions with a party during the current year exceeds $10 \%$ of lagged revenue (i.e. the threshold prescribed by SEBI), all transactions with the party are classified as material.

The second example illustrates how firm X, Y and Z are classified into treated and control groups given their material RPTs from financial year 2012 to 2014.

\begin{tabular}{|c|c|c|c|c|c|c|c|c|c|}
\hline & Related Party & $\begin{array}{l}3 \text { Tyре } \\
\text { Tyре A }\end{array}$ & $\begin{array}{l}\text { s of Trans } \\
\text { Type B }\end{array}$ & $\begin{array}{l}\text { actions } \\
\text { Type C }\end{array}$ & $\begin{array}{c}\text { RPT for } \\
\text { Each Party }\end{array}$ & $\begin{array}{c}\text { RPT/Past } \\
\text { Revenue }\end{array}$ & Material? & $\begin{array}{l}\text { Total } \\
\text { RPT }\end{array}$ & $\begin{array}{c}\text { Material } \\
\text { RPT }\end{array}$ \\
\hline Firm A & Party No. 1 & 8 & 5 & 2 & 15 & $15 \%$ & Yes & & \\
\hline (Past Revenue & Party No. 2 & 0 & 5 & 0 & 5 & $5 \%$ & No & 25 & 15 \\
\hline$=100)$ & Party No. 3 & 3 & 0 & 2 & 5 & $5 \%$ & No & & \\
\hline$\overline{\mathrm{Firm}} \overline{\mathrm{B}}$ & Party No. 1 & $\overline{0}$ & $7^{-}$ & 0 & $\overline{7}$ & $\overline{7} \overline{\%}$ & $\mathrm{~N}_{\mathrm{o}}^{-}$ & & \\
\hline (Past Revenue & Party No. 2 & 0 & 5 & 2 & 7 & $7 \%$ & No & 20 & 0 \\
\hline$=100)$ & Party No. 3 & 3 & 0 & 3 & 6 & $6 \%$ & No & & \\
\hline
\end{tabular}

\begin{tabular}{lcccc} 
& Pre-Treatment "Material" & RPT $>0$ ? & \\
& 2012 & 2013 & 2014 & Classification \\
\hline Firm X & Yes & Yes & Yes & Treated \\
Firm Y & Yes & No & No & Control \\
Firm Z & No & No & No & Control \\
\hline
\end{tabular}




\section{Internet Appendix}

Table AI

Industry Distribution

\begin{tabular}{lccccc}
\hline Industry & \multicolumn{2}{c}{ Control } & \multicolumn{2}{c}{ Treated } & Total RPT \\
& Number of Firms & Percentage & Number of Firms & Percentage & (Full Sample) \\
\hline Agriculture & 26 & $1.9 \%$ & 0 & $0.0 \%$ & 0.280 \\
Communication & 68 & $5.0 \%$ & 46 & $12.8 \%$ & 0.312 \\
Construction & 67 & $4.9 \%$ & 30 & $8.3 \%$ & 0.271 \\
Entertainment & 7 & $0.5 \%$ & 4 & $1.1 \%$ & 0.359 \\
Finance & 174 & $12.8 \%$ & 70 & $19.4 \%$ & 0.330 \\
Health & 10 & $0.7 \%$ & 3 & $0.8 \%$ & 0.289 \\
Hotel \& Food Service & 20 & $1.5 \%$ & 9 & $2.5 \%$ & 0.172 \\
Manufacturing & 711 & $52.4 \%$ & 124 & $34.4 \%$ & 0.244 \\
Mining & 15 & $1.1 \%$ & 4 & $1.1 \%$ & 0.140 \\
Other & 42 & $3.1 \%$ & 9 & $2.5 \%$ & 0.213 \\
Real Estate & 15 & $1.1 \%$ & 6 & $1.7 \%$ & 0.261 \\
Retail & 145 & $10.7 \%$ & 31 & $8.6 \%$ & 0.381 \\
Business Service & 40 & $2.9 \%$ & 7 & $1.9 \%$ & 0.400 \\
Transportation & 9 & $0.7 \%$ & 10 & $2.8 \%$ & 0.207 \\
Utility & 7 & $0.5 \%$ & 7 & $1.9 \%$ & 0.257 \\
\hline
\end{tabular}




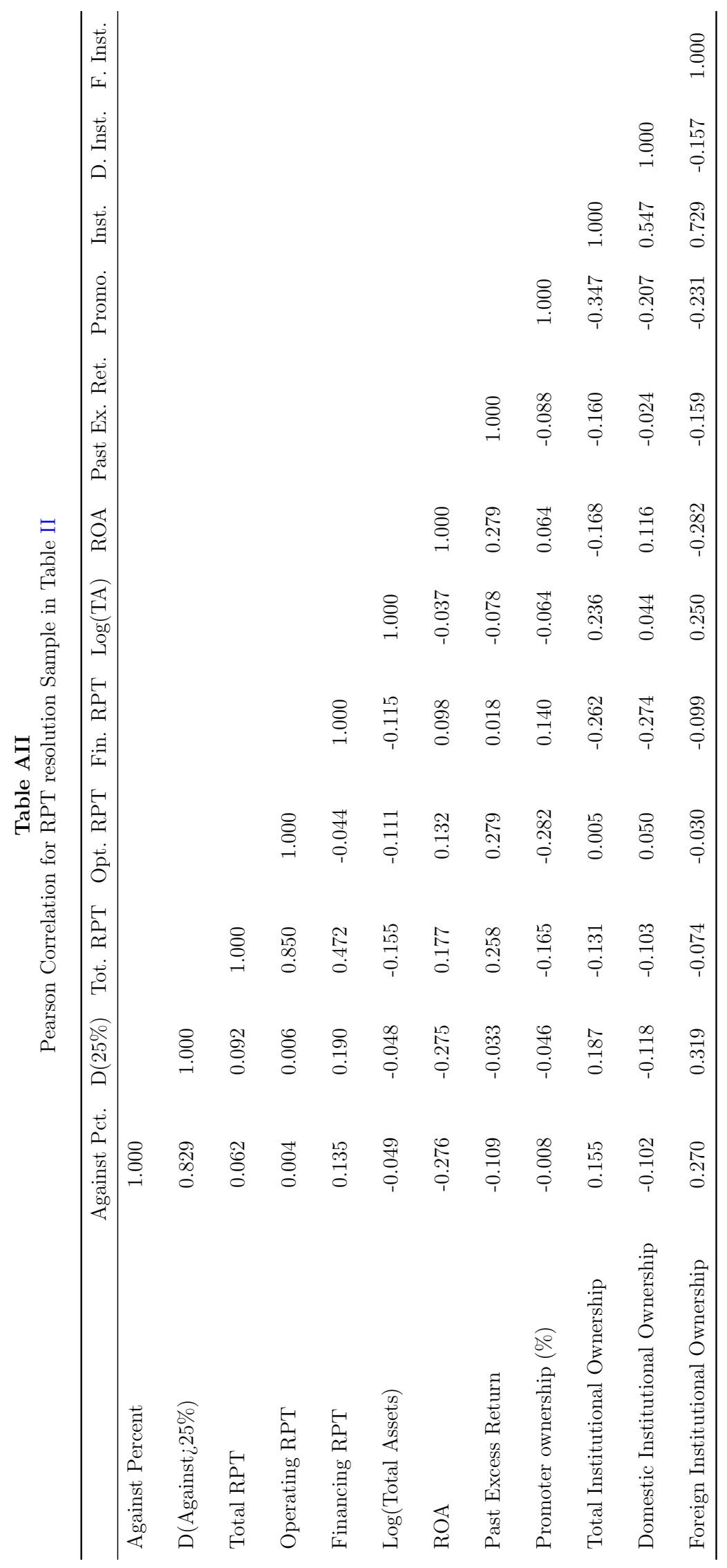




\section{Table AIII}

Consequences to Shareholder Dissent

Total RPT

\begin{tabular}{|c|c|c|}
\hline & Dissent Firms & Non-dissent Firms \\
\hline $\mathrm{T}-1$ & 0.272 & 0.315 \\
\hline $\mathrm{T}$ & 0.249 & 0.326 \\
\hline $\mathrm{T}+1$ & 0.218 & 0.307 \\
\hline \multicolumn{3}{|c|}{ Operating RPT } \\
\hline & Dissent Firms & Non-dissent Firms \\
\hline $\mathrm{T}-1$ & 0.134 & 0.229 \\
\hline $\mathrm{T}$ & 0.144 & 0.236 \\
\hline $\mathrm{T}+1$ & 0.133 & 0.209 \\
\hline
\end{tabular}

Financing RPT

\begin{tabular}{lcc}
\hline & Dissent Firms & Non-dissent Firms \\
$\mathrm{T}-1$ & 0.137 & 0.086 \\
$\mathrm{~T}$ & 0.104 & 0.091 \\
$\mathrm{~T}+1$ & 0.073 & 0.098 \\
\hline
\end{tabular}


Table AIV

Robustness: Controlling for Past ROA and Ownership

\begin{tabular}{|c|c|c|c|c|c|c|}
\hline \multirow[t]{2}{*}{ Outcome Variable } & \multicolumn{2}{|c|}{ Total RPT } & \multicolumn{2}{|c|}{ Operating RPT } & \multicolumn{2}{|c|}{ Financing RPT } \\
\hline & (1) & $(2)$ & $(3)$ & (4) & $(5)$ & (6) \\
\hline \multirow[t]{2}{*}{ Treated $\times$ Post } & $-0.070 * * *$ & $-0.075 * * *$ & -0.017 & -0.019 & $-0.048 * * *$ & $-0.039 * * *$ \\
\hline & $(-3.06)$ & $(-3.13)$ & $(-1.32)$ & $(-1.39)$ & $(-3.53)$ & $(-2.75)$ \\
\hline \multirow[t]{2}{*}{ Log(Total Assets) } & $0.085^{* *}$ & $0.094^{* *}$ & -0.009 & -0.011 & $0.072^{* * *}$ & $0.080^{* * *}$ \\
\hline & $(2.09)$ & $(2.23)$ & $(-0.44)$ & $(-0.65)$ & $(3.68)$ & $(3.84)$ \\
\hline \multirow[t]{2}{*}{ Leverage } & $0.209 * * *$ & $0.184^{*}$ & -0.040 & -0.015 & $0.175^{* * *}$ & $0.122^{* *}$ \\
\hline & $(2.79)$ & $(1.79)$ & $(-1.36)$ & $(-0.45)$ & $(4.27)$ & $(2.45)$ \\
\hline \multirow[t]{2}{*}{ Past ROA } & 0.064 & 0.027 & 0.030 & -0.001 & 0.040 & 0.029 \\
\hline & $(0.68)$ & $(0.32)$ & $(0.77)$ & $(-0.03)$ & $(0.69)$ & $(0.65)$ \\
\hline \multirow[t]{2}{*}{ Promoter Ownership } & -0.217 & -0.134 & -0.137 & -0.082 & -0.046 & 0.003 \\
\hline & $(-1.21)$ & $(-0.99)$ & $(-1.50)$ & $(-1.27)$ & $(-0.55)$ & $(0.04)$ \\
\hline \multirow[t]{2}{*}{ Domestic Inst. Ownership } & -0.081 & -0.119 & -0.096 & -0.087 & -0.012 & -0.007 \\
\hline & $(-0.51)$ & $(-1.01)$ & $(-1.40)$ & $(-1.42)$ & $(-0.14)$ & $(-0.11)$ \\
\hline \multirow[t]{2}{*}{ Foregin Inst. Ownership } & 0.109 & 0.087 & $0.132^{*}$ & $0.163^{* *}$ & -0.007 & -0.061 \\
\hline & $(0.78)$ & $(0.66)$ & $(1.74)$ & $(2.04)$ & $(-0.07)$ & $(-0.75)$ \\
\hline \multirow[t]{2}{*}{ Past Excess Return } & 0.008 & $0.012^{*}$ & 0.003 & 0.002 & 0.004 & $0.006^{*}$ \\
\hline & $(1.08)$ & $(1.80)$ & $(0.90)$ & $(0.62)$ & $(0.89)$ & $(1.79)$ \\
\hline \multirow[t]{2}{*}{ Auditor Switch } & & 0.018 & & 0.005 & & 0.010 \\
\hline & & $(1.21)$ & & $(0.46)$ & & $(0.95)$ \\
\hline \multirow[t]{2}{*}{ Log(CEO Pay) } & & 0.004 & & 0.000 & & 0.002 \\
\hline & & $(0.86)$ & & $(0.08)$ & & $(0.63)$ \\
\hline \multirow[t]{2}{*}{ Pct. New Director } & & $0.107^{* *}$ & & 0.035 & & $0.045^{* *}$ \\
\hline & & $(2.55)$ & & $(1.54)$ & & $(2.03)$ \\
\hline \multirow[t]{2}{*}{ Board Independence } & & -0.050 & & -0.034 & & -0.033 \\
\hline & & $(-0.93)$ & & $(-1.09)$ & & $(-1.01)$ \\
\hline \multirow[t]{2}{*}{ Audit. Com. Independence } & & -0.013 & & 0.014 & & -0.003 \\
\hline & & $(-0.36)$ & & $(0.64)$ & & $(-0.14)$ \\
\hline \multirow[t]{2}{*}{ CSR Expenditure } & & -2.275 & & -5.299 & & 2.640 \\
\hline & & $(-0.36)$ & & $(-0.95)$ & & $(0.63)$ \\
\hline Number of Observations & 7574 & 5839 & 7574 & 5839 & 7574 & 5839 \\
\hline Number of Firms & 1716 & 1577 & 1716 & 1577 & 1716 & 1577 \\
\hline Fixed Effects & Firm, Year & Firm, Year & Firm, Year & Firm, Year & Firm, Year & Firm, Year \\
\hline Basic Control & Yes & Yes & Yes & Yes & Yes & Yes \\
\hline Additional Control & No & Yes & No & Yes & No & Yes \\
\hline
\end{tabular}


Table AV

Robustness: Controlling for Average RPT-to-Revenue (Pre) Interacting with Post

\begin{tabular}{lcccccc}
\hline Outcome Variable & \multicolumn{2}{c}{ Total RPT } & \multicolumn{2}{c}{ Operating RPT } & \multicolumn{2}{c}{ Financing RPT } \\
\hline \multirow{2}{*}{ Treated $\times$ Post } & $(1)$ & $(2)$ & $(3)$ & $(4)$ & $(5)$ & $(6)$ \\
& $\mathbf{- 0 . 0 5 4 ^ { * * }}$ & $\mathbf{- 0 . 0 5 4 ^ { * * }}$ & $\mathbf{- 0 . 0 1 5}$ & $\mathbf{- 0 . 0 2 0}$ & $\mathbf{- 0 . 0 3 5 ^ { * * * }}$ & $\mathbf{- 0 . 0 2 5 ^ { * }}$ \\
& $\mathbf{( - 2 . 3 8 )}$ & $\mathbf{( - 2 . 3 7 )}$ & $\mathbf{( - 1 . 0 1 )}$ & $\mathbf{( - 1 . 4 8 )}$ & $\mathbf{( - 2 . 7 6 )}$ & $\mathbf{( - 1 . 8 7 )}$ \\
RPT/Revenue_Pre $\times$ Post & $-0.011^{* * *}$ & $-0.011^{* *}$ & $-0.003^{*}$ & 0.000 & $-0.007^{* * *}$ & $-0.007^{*}$ \\
& $(-3.91)$ & $(-2.07)$ & $(-1.90)$ & $(0.45)$ & $(-3.89)$ & $(-1.91)$ \\
Number of Observations & & & & & & \\
Number of Firms & 1743 & 5921 & 7743 & 5921 & 7743 & 5921 \\
Fixed Effects & 1716 & 1583 & 1716 & 1583 & 1716 & 1583 \\
Basic Control & Firm, Year & Firm, Year & Firm, Year & Firm, Year & Firm, Year & Firm, Year \\
Additional Control & Yes & Yes & Yes & Yes & Yes & Yes \\
\hline & No & Yes & No & Yes & No & Yes \\
\hline
\end{tabular}

Table AVI

Robustness: Excluding Firms with Potentially Treated Parties

\begin{tabular}{lcccccc}
\hline Outcome Variable & \multicolumn{2}{c}{ Total RPT } & \multicolumn{2}{c}{ Operating RPT } & \multicolumn{2}{c}{ Financing RPT } \\
\hline \multirow{2}{*}{ Treated* Post } & $(1)$ & $(2)$ & $(3)$ & $(4)$ & $(5)$ & $(6)$ \\
& $\mathbf{- 0 . 0 7 7 ^ { * * * }}$ & $\mathbf{- 0 . 0 6 9 * * *}$ & $\mathbf{- 0 . 0 1 6}$ & $\mathbf{- 0 . 0 1 0}$ & $\mathbf{- 0 . 0 5 5 ^ { * * * }}$ & $\mathbf{- 0 . 0 4 2 * * *}$ \\
& $\mathbf{( - 2 . 9 9 )}$ & $\mathbf{( - 2 . 6 5 )}$ & $\mathbf{( - 1 . 0 7 )}$ & $\mathbf{( - 0 . 6 8 )}$ & $\mathbf{( - 3 . 6 8 )}$ & $\mathbf{( - 2 . 6 9 )}$ \\
Number of Observations & 6869 & 5233 & 6869 & 5233 & & \\
Number of Firms & 1527 & 1407 & 1527 & 1407 & 1527 & 5233 \\
Fixed Effects & Firm, Year & Firm, Year & Firm, Year & Firm, Year & Firm, Year & Firm, Year \\
Basic Control & Yes & Yes & Yes & Yes & Yes & Yes \\
Additional Control & No & Yes & No & Yes & No & Yes \\
\hline
\end{tabular}


Table AVII

Robustness: Alternative Measurement of RPT Variables

Panel A

\begin{tabular}{lccc}
\hline Outcome Variable & $\log (1+$ Total RPT $)$ & $\log (1+$ Operating RPT $)$ & $\log (1+$ Financing RPT $)$ \\
\hline Treated $\times$ Post & $(1)$ & $(3)$ & $(5)$ \\
& $-0.194^{* * *}$ & -0.039 & $-0.209^{* *}$ \\
Number of Observations & $(-3.02)$ & $(-0.55)$ & $(-2.37)$ \\
Fixed Effects & 7743 & & 7743 \\
Basic Control & Firm, Year & Firm, Year & Firm, Year \\
Additional Control & Yes & Yes & Yes \\
\hline & No & No & No \\
Panel B & & & \\
\hline Outcome Variable & Total RPT/Sales & Operating RPT/Sales & Financing RPT/Sales \\
\hline & $(2)$ & $(4)$ & $(6)$ \\
Treated $\times$ Post & $-0.305^{*}$ & $-0.049^{* *}$ & $-0.254^{* *}$ \\
& $(-1.95)$ & $(-2.46)$ & $(-2.03)$ \\
Number of Observations & 7743 & 7743 & 7743 \\
Fixed Effects & Firm, Year & Firm, Year & Firm, Year \\
Basic Control & Yes & Yes & Yes \\
Additional Control & No & No & No \\
\hline
\end{tabular}


Table AVIII

Robustness: Alternative Control Group Definition

\begin{tabular}{lccc}
\hline Outcome Variable & Total RPT & Operating RPT & Financing RPT \\
\hline & $(1)$ & $(2)$ & $(3)$ \\
Treated $\times$ Post & $-0.112^{* * *}$ & $-0.041^{* * *}$ & $-0.064^{* * *}$ \\
& $(-4.92)$ & $(-3.13)$ & $(-4.91)$ \\
Number of Observations & 4762 & 4762 & 4762 \\
Fixed Effects & Firm, Year & Firm, Year & Firm, Year \\
Basic Control & Yes & Yes & Yes \\
Additional Control & No & No & No \\
\hline
\end{tabular}


Table AIX

Pre-Treatment Characteristics: Matching and Entropy Balancing

Panel A: Propensity Score Matching Covariate Balance

\begin{tabular}{|c|c|c|c|c|}
\hline \multirow[b]{2}{*}{ Variable Name } & \multicolumn{2}{|c|}{ Treated } & \multicolumn{2}{|c|}{ Control } \\
\hline & Number of Firms & Mean & Number of Firms & Mean \\
\hline Total Assets (log), 2012 & 351 & 7.658 & 351 & 7.726 \\
\hline Total Assets (log), 2013 & 351 & 7.721 & 351 & 7.791 \\
\hline Total Assets (log), 2014 & 351 & 7.784 & 351 & 7.842 \\
\hline leverage, 2012 & 351 & 0.329 & 351 & 0.329 \\
\hline leverage, 2013 & 351 & 0.336 & 351 & 0.333 \\
\hline leverage, 2014 & 351 & 0.351 & 351 & 0.347 \\
\hline Past Excess Return, 2012 & 351 & -0.041 & 351 & -0.016 \\
\hline Past Excess Return, 2013 & 351 & -0.017 & 351 & -0.005 \\
\hline Past Excess Return, 2014 & 351 & -0.013 & 351 & -0.022 \\
\hline ROA, 2012 & 351 & 0.026 & 351 & 0.030 \\
\hline ROA, 2013 & 351 & 0.027 & 351 & 0.029 \\
\hline ROA, 2014 & 351 & 0.023 & 351 & 0.028 \\
\hline Promoter ownership, 2012 & 351 & 0.542 & 351 & 0.548 \\
\hline Promoter ownership, 2013 & 351 & 0.542 & 351 & 0.549 \\
\hline Promoter ownership, 2014 & 351 & 0.541 & 351 & 0.547 \\
\hline \multicolumn{5}{|c|}{ Panel B: Entropy Balancing Covariate Balance } \\
\hline & \multicolumn{2}{|c|}{ Treated } & \multicolumn{2}{|c|}{ Control } \\
\hline Variable Name & Number of Firms & Weighted Mean & Number of Firms & Weighted Mean \\
\hline Total Assets (log), 2012 & 351 & 7.658 & 972 & 7.658 \\
\hline Total Assets (log), 2013 & 351 & 7.721 & 972 & 7.721 \\
\hline Total Assets (log), 2014 & 351 & 7.784 & 972 & 7.784 \\
\hline leverage, 2012 & 351 & 0.329 & 972 & 0.329 \\
\hline leverage, 2013 & 351 & 0.336 & 972 & 0.336 \\
\hline leverage, 2014 & 351 & 0.351 & 972 & 0.351 \\
\hline Past Excess Return, 2012 & 351 & -0.041 & 972 & -0.041 \\
\hline Past Excess Return, 2013 & 351 & -0.017 & 972 & -0.017 \\
\hline Past Excess Return, 2014 & 351 & -0.013 & 972 & -0.013 \\
\hline ROA, 2012 & 351 & 0.026 & 972 & 0.026 \\
\hline ROA, 2013 & 351 & 0.027 & 972 & 0.027 \\
\hline ROA, 2014 & 351 & 0.023 & 972 & 0.023 \\
\hline Promoter ownership, 2012 & 351 & 0.542 & 972 & 0.542 \\
\hline Promoter ownership, 2013 & 351 & 0.542 & 972 & 0.542 \\
\hline Promoter ownership, 2014 & 351 & 0.541 & 972 & 0.541 \\
\hline
\end{tabular}


Table AX

Difference-in-Difference Estimation with Matched Sample

Panel A: RPT level

\begin{tabular}{|c|c|c|c|c|c|c|}
\hline \multirow{2}{*}{$\begin{array}{l}\text { Outcome Variable } \\
\text { Treated* Post }\end{array}$} & \multicolumn{2}{|c|}{ Total RPT } & \multicolumn{2}{|c|}{ Operating RPT } & \multicolumn{2}{|c|}{ Financing RPT } \\
\hline & $\begin{array}{c}(1) \\
-0.108^{* * *} \\
(-4.11)\end{array}$ & $\begin{array}{c}(2) \\
-0.091^{* * *} \\
(-3.69)\end{array}$ & $\begin{array}{c}(3) \\
-0.032^{* *} \\
(-2.23)\end{array}$ & $\begin{array}{c}(4) \\
-0.031^{* *} \\
(-2.13)\end{array}$ & $\begin{array}{c}(5) \\
-0.062^{* * *} \\
(-4.19)\end{array}$ & $\begin{array}{c}(6) \\
-0.043^{* * *} \\
(-2.95)\end{array}$ \\
\hline $\begin{array}{l}\text { Number of Observations } \\
\text { Fixed Effects } \\
\text { Basic Control } \\
\text { Additional Control }\end{array}$ & $\begin{array}{c}3348 \\
\text { Firm, Year } \\
\text { Yes } \\
\text { No }\end{array}$ & $\begin{array}{c}2647 \\
\text { Firm, Year } \\
\text { Yes } \\
\text { Yes }\end{array}$ & $\begin{array}{c}3348 \\
\text { Firm, Year } \\
\text { Yes } \\
\text { No }\end{array}$ & $\begin{array}{c}2647 \\
\text { Firm, Year } \\
\text { Yes } \\
\text { Yes }\end{array}$ & $\begin{array}{c}3348 \\
\text { Firm, Year } \\
\text { Yes } \\
\text { No }\end{array}$ & $\begin{array}{c}2647 \\
\text { Firm, Year } \\
\text { Yes } \\
\text { Yes }\end{array}$ \\
\hline \multicolumn{7}{|c|}{ Panel B: RPT and Profitability } \\
\hline \multicolumn{7}{|c|}{ Outcome Variable: Return on Assets } \\
\hline RPT*Treated*Post & $\begin{array}{c}(1) \\
0.023 \\
(1.12)\end{array}$ & $\begin{array}{c}(2) \\
0.027^{*} \\
(1.67)\end{array}$ & $\begin{array}{c}(3) \\
-0.010 \\
(-0.45)\end{array}$ & $\begin{array}{c}(4) \\
0.007 \\
(0.32)\end{array}$ & $\begin{array}{c}(5) \\
0.063^{* *} \\
(2.06)\end{array}$ & $\begin{array}{c}(6) \\
0.083^{* * *} \\
(2.67)\end{array}$ \\
\hline $\begin{array}{l}\text { Number of Observations } \\
\text { Fixed Effects } \\
\text { Basic Control } \\
\text { Additional Control }\end{array}$ & $\begin{array}{c}3348 \\
\text { Firm, Year } \\
\text { Yes } \\
\text { No }\end{array}$ & $\begin{array}{c}2647 \\
\text { Firm, Year } \\
\text { Yes } \\
\text { Yes }\end{array}$ & $\begin{array}{c}3348 \\
\text { Firm, Year } \\
\text { Yes } \\
\text { No }\end{array}$ & $\begin{array}{c}2647 \\
\text { Firm, Year } \\
\text { Yes } \\
\text { Yes }\end{array}$ & $\begin{array}{c}3348 \\
\text { Firm, Year } \\
\text { Yes } \\
\text { No }\end{array}$ & $\begin{array}{c}2647 \\
\text { Firm, Year } \\
\text { Yes } \\
\text { Yes }\end{array}$ \\
\hline \multicolumn{7}{|c|}{ Panel C: institutional Holding } \\
\hline Outcome Variable & Total Inst. & Ownership & Domestic Ir & Ownership & Foreign Inst & Ownership \\
\hline Treated* Post & $\begin{array}{c}(1) \\
0.010^{* *} \\
(2.02)\end{array}$ & $\begin{array}{c}(2) \\
0.008 \\
(1.39)\end{array}$ & $\begin{array}{c}(3) \\
0.005 \\
(1.14)\end{array}$ & $\begin{array}{c}(4) \\
0.001 \\
(0.19)\end{array}$ & $\begin{array}{l}(5) \\
0.005^{*} \\
(1.71)\end{array}$ & $\begin{array}{c}(6) \\
0.007^{* *} \\
(2.05)\end{array}$ \\
\hline $\begin{array}{l}\text { Number of Observations } \\
\text { Fixed Effects } \\
\text { Basic Control } \\
\text { Additional Control }\end{array}$ & $\begin{array}{c}3342 \\
\text { Firm, Year } \\
\text { Yes } \\
\text { No }\end{array}$ & $\begin{array}{c}2644 \\
\text { Firm, Year } \\
\text { Yes } \\
\text { Yes }\end{array}$ & $\begin{array}{c}3342 \\
\text { Firm, Year } \\
\text { Yes } \\
\text { No }\end{array}$ & $\begin{array}{c}2644 \\
\text { Firm, Year } \\
\text { Yes } \\
\text { Yes }\end{array}$ & $\begin{array}{c}3342 \\
\text { Firm, Year } \\
\text { Yes } \\
\text { No }\end{array}$ & $\begin{array}{c}2644 \\
\text { Firm, Year } \\
\text { Yes } \\
\text { Yes }\end{array}$ \\
\hline
\end{tabular}


Table AXI

Difference-in-Difference Estimation with Entropy Balancing

Panel A: RPT level

\begin{tabular}{|c|c|c|c|c|c|c|}
\hline \multirow{2}{*}{$\begin{array}{l}\text { Outcome Variable } \\
\text { Treated* Post }\end{array}$} & \multicolumn{2}{|c|}{ Total RPT } & \multicolumn{2}{|c|}{ Operating RPT } & \multicolumn{2}{|c|}{ Financing RPT } \\
\hline & $\begin{array}{c}(1) \\
-0.121^{* * *} \\
(-3.87)\end{array}$ & $\begin{array}{c}(2) \\
-0.104^{* * *} \\
(-3.89)\end{array}$ & $\begin{array}{c}(3) \\
-0.028^{* *} \\
(-2.07)\end{array}$ & $\begin{array}{c}(4) \\
-0.024^{*} \\
(-1.79)\end{array}$ & $\begin{array}{c}(5) \\
-0.072^{* * *} \\
(-4.27)\end{array}$ & $\begin{array}{c}(6) \\
-0.054^{* * *} \\
(-3.40)\end{array}$ \\
\hline $\begin{array}{l}\text { Number of Observations } \\
\text { Fixed Effects } \\
\text { Basic Control } \\
\text { Additional Control }\end{array}$ & $\begin{array}{c}6320 \\
\text { Firm, Year } \\
\text { Yes } \\
\text { No }\end{array}$ & $\begin{array}{c}5093 \\
\text { Firm, Year } \\
\text { Yes } \\
\text { Yes }\end{array}$ & $\begin{array}{c}6320 \\
\text { Firm, Year } \\
\text { Yes } \\
\text { No }\end{array}$ & $\begin{array}{c}5093 \\
\text { Firm, Year } \\
\text { Yes } \\
\text { Yes }\end{array}$ & $\begin{array}{c}6320 \\
\text { Firm, Year } \\
\text { Yes } \\
\text { No }\end{array}$ & $\begin{array}{c}5093 \\
\text { Firm, Year } \\
\text { Yes } \\
\text { Yes }\end{array}$ \\
\hline \multicolumn{7}{|c|}{ Panel B: RPT and Profitability } \\
\hline \multicolumn{7}{|c|}{ Outcome Variable: Return on Assets } \\
\hline RPT*Treated*Post & $\begin{array}{c}(1) \\
0.023 \\
(1.12)\end{array}$ & $\begin{array}{c}(2) \\
0.027^{*} \\
(1.67)\end{array}$ & $\begin{array}{c}(3) \\
-0.010 \\
(-0.45)\end{array}$ & $\begin{array}{c}(4) \\
0.007 \\
(0.32)\end{array}$ & $\begin{array}{c}(5) \\
0.063^{* *} \\
(2.06)\end{array}$ & $\begin{array}{c}(6) \\
0.083^{* * *} \\
(2.67)\end{array}$ \\
\hline $\begin{array}{l}\text { Number of Observations } \\
\text { Fixed Effects } \\
\text { Basic Control } \\
\text { Additional Control }\end{array}$ & $\begin{array}{c}6320 \\
\text { Firm, Year } \\
\text { Yes } \\
\text { No }\end{array}$ & $\begin{array}{c}5093 \\
\text { Firm, Year } \\
\text { Yes } \\
\text { Yes }\end{array}$ & $\begin{array}{c}6320 \\
\text { Firm, Year } \\
\text { Yes } \\
\text { No }\end{array}$ & $\begin{array}{c}5093 \\
\text { Firm, Year } \\
\text { Yes } \\
\text { Yes }\end{array}$ & $\begin{array}{c}6320 \\
\text { Firm, Year } \\
\text { Yes } \\
\text { No }\end{array}$ & $\begin{array}{c}5093 \\
\text { Firm, Year } \\
\text { Yes } \\
\text { Yes }\end{array}$ \\
\hline \multicolumn{7}{|c|}{ Panel C: institutional Holding } \\
\hline Outcome Variable & Total Inst. & Ownership & Domestic Ir & Ownership & Foreign Inst & Ownership \\
\hline Treated* Post & $\begin{array}{c}(1) \\
0.007 \\
(1.61)\end{array}$ & $\begin{array}{c}(2) \\
0.004 \\
(0.86)\end{array}$ & $\begin{array}{c}(3) \\
0.002 \\
(0.60)\end{array}$ & $\begin{array}{c}(4) \\
-0.003 \\
(-0.60)\end{array}$ & $\begin{array}{c}(5) \\
0.005^{* *} \\
(2.01)\end{array}$ & $\begin{array}{c}(6) \\
0.007^{* *} \\
(2.44)\end{array}$ \\
\hline $\begin{array}{l}\text { Number of Observations } \\
\text { Fixed Effects } \\
\text { Basic Control } \\
\text { Additional Control }\end{array}$ & $\begin{array}{c}6312 \\
\text { Firm, Year } \\
\text { Yes } \\
\text { No }\end{array}$ & $\begin{array}{c}5089 \\
\text { Firm, Year } \\
\text { Yes } \\
\text { Yes }\end{array}$ & $\begin{array}{c}6312 \\
\text { Firm, Year } \\
\text { Yes } \\
\text { No }\end{array}$ & $\begin{array}{c}5089 \\
\text { Firm, Year } \\
\text { Yes } \\
\text { Yes }\end{array}$ & $\begin{array}{c}6312 \\
\text { Firm, Year } \\
\text { Yes } \\
\text { No }\end{array}$ & $\begin{array}{c}5089 \\
\text { Firm, Year } \\
\text { Yes } \\
\text { Yes }\end{array}$ \\
\hline
\end{tabular}


Table AXII

Placebo Test

\begin{tabular}{lcccc}
\hline Outcome Variable & Total RPT & Operating RPT & Financing RPT & Total Inst. Ownership \\
\hline \multirow{4}{*}{ Treated $\times$ Post } & $(1)$ & $(2)$ & $(3)$ & $(4)$ \\
& 0.010 & -0.021 & 0.018 & 0.004 \\
& $(0.21)$ & $(-0.58)$ & $(0.96)$ & $(0.36)$ \\
Number of Observations & 5398 & 5398 & 5398 & 5193 \\
Fixed Effects & Firm, Year & Firm, Year & Firm, Year & Firm, Year \\
Basic Control & Yes & Yes & Yes & Yes \\
Additional Control & No & No & No & No \\
\hline
\end{tabular}


Table AXIII

Probability of Positive Interest Income or Expense

\begin{tabular}{|c|c|c|c|c|}
\hline Outcome Variable & $\mathrm{D}$ (Interes & t Income) & $\mathrm{D}$ (Interes & Expense) \\
\hline Treated $\times$ Post & $\begin{array}{c}(1) \\
0.050^{*} \\
(1.69)\end{array}$ & $\begin{array}{c}(2) \\
0.064^{*} \\
(1.82)\end{array}$ & $\begin{array}{c}(3) \\
-0.037 \\
(-1.12)\end{array}$ & $\begin{array}{c}(4) \\
-0.054 \\
(-1.32)\end{array}$ \\
\hline $\begin{array}{l}\text { Number of Observations } \\
\text { Fixed Effects } \\
\text { Basic Control } \\
\text { Additional Control }\end{array}$ & $\begin{array}{c}3299 \\
\text { Firm, Year } \\
\text { Yes } \\
\text { No }\end{array}$ & $\begin{array}{c}2683 \\
\text { Firm, Year } \\
\text { Yes } \\
\text { Yes }\end{array}$ & $\begin{array}{c}2382 \\
\text { Firm, Year } \\
\text { Yes } \\
\text { No }\end{array}$ & $\begin{array}{c}1757 \\
\text { Firm, Year } \\
\text { Yes } \\
\text { Yes }\end{array}$ \\
\hline
\end{tabular}




\title{
Appendix A1: Examples of Related Party Transaction Resolution and Accounting Disclosure
}

\author{
United Spirits Ltd. Voting Outcome (Financial Year 2015)
}

10.4 During the year, two Extraordinary General Meetings were held alnd the details are as follows:

\begin{tabular}{|c|c|c|c|}
\hline $\begin{array}{l}\text { Date of Notice } \\
\text { of Extraordinary } \\
\text { General Meeting \& } \\
\text { Date of Meeting }\end{array}$ & $\begin{array}{l}\text { Date of } \\
\text { Results }\end{array}$ & Description & Results \\
\hline $\begin{array}{l}\text { October } 31,2014 \& \\
\text { November } 28,2014\end{array}$ & $\begin{array}{l}\text { November } \\
29,2014\end{array}$ & $\begin{array}{l}\text { 1. Considering erosion of net worth of the Company as per } \\
\text { Section } 23 \text { of the Sick Industrial Companies (Special Provisions) } \\
\text { Act, } 1985 \text { (SICA) }\end{array}$ & $\begin{array}{l}\text { Resolution carried with } \\
\text { requisite majority }\end{array}$ \\
\hline $\begin{array}{l}\text { October } 31,2014 \& \\
\text { November } 28,2014\end{array}$ & $\begin{array}{l}\text { November } \\
29,2014\end{array}$ & $\begin{array}{l}\text { 2. Approval of sales promotion services agreement dated } \\
\text { October 1, 2013, between the Company and Diageo India } \\
\text { Private Limited, which may qualify as an existing material } \\
\text { related party transaction entered into by the Company }\end{array}$ & $\begin{array}{l}\text { Resolution carried with } \\
\text { requisite majority }\end{array}$ \\
\hline $\begin{array}{l}\text { October } 31,2014 \& \\
\text { November } 28,2014\end{array}$ & $\begin{array}{l}\text { November } \\
29,2014\end{array}$ & $\begin{array}{l}\text { 3. Approval of loan agreement dated July } 3,2013 \text {, between the } \\
\text { Company and United Breweries (Holdings) Limited, which } \\
\text { may qualify as an existing material related party transaction } \\
\text { entered into by the Company }\end{array}$ & $\begin{array}{l}\text { Resolution not carried } \\
\text { with requisite majority }\end{array}$ \\
\hline $\begin{array}{l}\text { October } 31,2014 \& \\
\text { November } 28,2014\end{array}$ & $\begin{array}{l}\text { November } \\
29,2014\end{array}$ & $\begin{array}{l}\text { 4. Approval of trademark licence agreement dated June 29, } \\
2013 \text {, between the Company and United Breweries (Holdings) } \\
\text { Limited, which may qualify as an existing material related } \\
\text { party transaction entered into by the Company }\end{array}$ & $\begin{array}{l}\text { Resolution carried with } \\
\text { requisite majority }\end{array}$ \\
\hline $\begin{array}{l}\text { October } 31,2014 \& \\
\text { November } 28,2014\end{array}$ & $\begin{array}{l}\text { November } \\
29,2014\end{array}$ & $\begin{array}{l}\text { 5. Approval of agreements dated September 30, } 2011 \text { and } \\
\text { December 22, } 2011 \text { respectively, between the Company } \\
\text { and United Breweries (Holdings) Limited requiring United } \\
\text { Breweries (Holdings) Limited to sell to the Company certain } \\
\text { immovable properties, which may qualify as existing material } \\
\text { related party transactions entered into by the Company }\end{array}$ & $\begin{array}{l}\text { Resolution not carried } \\
\text { with requisite majority }\end{array}$ \\
\hline $\begin{array}{l}\text { October } 31,2014 \& \\
\text { November } 28,2014\end{array}$ & $\begin{array}{l}\text { November } \\
29,2014\end{array}$ & $\begin{array}{l}\text { 6. Approval of services agreement dated July } 3,2013 \text {, between } \\
\text { the Company and Kingfisher Finvest India Limited, which } \\
\text { may qualify as an existing material related party transaction } \\
\text { entered into by the Company }\end{array}$ & $\begin{array}{l}\text { Resolution not carried } \\
\text { with requisite majority }\end{array}$ \\
\hline $\begin{array}{l}\text { October } 31,2014 \& \\
\text { November } 28,2014\end{array}$ & $\begin{array}{l}\text { November } \\
29,2014\end{array}$ & $\begin{array}{l}\text { 7. Approval of advertising agreement dated October 1, } 2013 \\
\text { (which amended and restated the original agreement dated } \\
\text { July } 3,2013 \text { ) between the Company and Watson Limited, } \\
\text { which may qualify as an existing material related party } \\
\text { transaction entered into by the Company }\end{array}$ & $\begin{array}{l}\text { Resolution not carried } \\
\text { with requisite majority }\end{array}$ \\
\hline $\begin{array}{l}\text { October } 31,2014 \& \\
\text { November } 28,2014\end{array}$ & $\begin{array}{l}\text { November } \\
29,2014\end{array}$ & $\begin{array}{l}\text { 8. Approval of sponsorship agreement dated June 11, } 2013 \\
\text { between the Company and United Racing \& Bloodstock } \\
\text { Breeders Limited, which may qualify as an existing material } \\
\text { related party transaction entered into by the Company }\end{array}$ & $\begin{array}{l}\text { Resolution not carried } \\
\text { with requisite majority }\end{array}$ \\
\hline $\begin{array}{l}\text { October } 31,2014 \& \\
\text { November } 28,2014\end{array}$ & $\begin{array}{l}\text { November } \\
29,2014\end{array}$ & $\begin{array}{l}\text { 9. Approval of sponsorship agreement dated June 11, } 2013 \\
\text { between the Company and United Mohun Bagan Football } \\
\text { Team Private Limited, which may qualify as an existing material } \\
\text { related party transaction entered into by the Company }\end{array}$ & $\begin{array}{l}\text { Resolution not carried } \\
\text { with requisite majority }\end{array}$ \\
\hline
\end{tabular}




\begin{tabular}{|c|c|c|c|}
\hline $\begin{array}{l}\text { Date of Notice } \\
\text { of Extraordinary } \\
\text { General Meeting \& } \\
\text { Date of Meeting }\end{array}$ & $\begin{array}{l}\text { Date of } \\
\text { Results }\end{array}$ & Description & Results \\
\hline $\begin{array}{l}\text { October } 31,2014 \& \\
\text { November } 28,2014\end{array}$ & $\begin{array}{l}\text { November } \\
29,2014\end{array}$ & $\begin{array}{l}\text { 10. Approval of aircraft services agreement dated June } 11,2013 \\
\text { between the Company and UB Air Private Limited, which } \\
\text { may qualify as an existing material related party transaction } \\
\text { entered into by the Company }\end{array}$ & $\begin{array}{l}\text { Resolution not carried } \\
\text { with requisite majority }\end{array}$ \\
\hline $\begin{array}{l}\text { October } 31,2014 \& \\
\text { November } 28,2014\end{array}$ & $\begin{array}{l}\text { November } \\
29,2014\end{array}$ & $\begin{array}{l}\text { 11. Approval of properties call agreement dated June } 11,2013 \\
\text { between the Company and PE Data Centre Resources Private } \\
\text { Limited, which may qualify as an existing material related } \\
\text { party transaction entered into by the Company }\end{array}$ & $\begin{array}{l}\text { Resolution not carried } \\
\text { with requisite majority }\end{array}$ \\
\hline $\begin{array}{l}\text { October } 31,2014 \& \\
\text { November } 28,2014\end{array}$ & $\begin{array}{l}\text { November } \\
29,2014\end{array}$ & $\begin{array}{l}\text { 12. Approval of contribution agreement dated June 11, } 2013 \\
\text { between the Company and Vittal Mallya Scientific Research } \\
\text { Foundation, which may qualify as an existing material related } \\
\text { party transaction entered into by the Company }\end{array}$ & $\begin{array}{l}\text { Resolution not carried } \\
\text { with requisite majority }\end{array}$ \\
\hline $\begin{array}{l}\text { December 12, } 2014 \\
\text { \& January 09, } 2015\end{array}$ & $\begin{array}{l}\text { January } \\
09,2015\end{array}$ & $\begin{array}{l}\text { Approval for entering into license for manufacture and sale } \\
\text { agreements, distribution agreement, cost sharing agreement } \\
\text { and such other and further agreements in connection with } \\
\text { the aforesaid agreements by the Company with certain } \\
\text { subsidiaries of Diageo plc, the Company's ultimate holding } \\
\text { company, as mentioned in the Notice dated December } 12 \text {, } \\
2014 \text {. }\end{array}$ & $\begin{array}{l}\text { Resolution carried with } \\
\text { requisite majority }\end{array}$ \\
\hline
\end{tabular}




\section{United Spirits Ltd. Related Party Footnote (Financial Year 2015)}

\section{Notes to the financial statements (continued)}

24. Related party disclosures (contd...)

Trading Co. Limited^, 19) Tern Distilleries Private Limited, 20) Sovereign Distilleries Limited, 21) Pioneer Distilleries Limited, 22) United Spirits Singapore Pte Limited (formerly known as "Whyte and Mackay Singapore Pte Limited")

Consequent to the sale of Whyte and Mackay, the following companies ceased to be subsidiaries with effect from 31 October 2014. 1) Whyte and Mackay Group Limited ^, 2) Whyte and Mackay Holdings Ltd $\wedge, 3$ ) Whyte and Mackay Limited (W\&M) 4) Whyte and Mackay Warehousing Limited $\wedge$, 5) Bruce \& Company (Leith) Limited^, 6) Charles Mackinlay \& Company Limited^, 7) Dalmore Distillers Limited^, 8) Dalmore Whyte \& Mackay Limited^, 9) Edinburgh Scotch Whisky Company Limited^, 10) Ewen \& Company Limited^, 11) Fettercairn Distillery Limited ^ 12) Findlater Scotch Whisky Limited^, 13) Glayva Liqueur Limited^ , 14) Glentalla Limited, 15) GPS Real isations Limited 16) Grey Rogers \& Company Limited^, 17) Hay \& MacLeod Limited^, 18) Invergordon Distillers (Holdings) Limited $\wedge$, 19) Invergordon Distillers Group Limited $\wedge$, 20) Invergordon Distillers Limited^, 21) Invergordon Gin Limited^, 22) Isle of Jura Distillery Company Limited 23) Jarvis Halliday \& Compary Limited^, 24) John E McPherson \& Sons Limited^ , 25) Kensington Distillers Limited^, 26) Kyndal Spirits Limited^, 27) Leith Distillers Limited^, 28) Loch Glass Distilling Company Limited^, 29) Longman Distillers Limited^, 30) Lycidas (437) Limited^, 31) Pentland Bonding Compary Limited^ , 32) Ronald Morrison \& Company Limited $\wedge$ 33) StThe Sheep Dip Whisky Company Limited^, 34) Vincent Street (437) Limited^, 35) Tamnavulin-Glenlivet Distillery Company Limited^, 36) TDL Realisations Limited^, 37) W \& S Strong Limited $\wedge, 38$ ) Watson \& Middleton Limited $\wedge, 39)$ Wauchope Moodie \& Company Limited $\wedge, 40)$ Whyte \& Mackay Distillers Limited $\wedge, 41$ ) William Muir Limited $\wedge$, 42) WMB Realisations Limited $\wedge, 43)$ Whyte and Mackay Property Limited $\wedge, 44)$ Whyte and Mackay de Venezuela $(A \wedge, 45) \mathrm{KI}$ Trustees Limited^, 46)Whyte and Mackay Americas Limited^

II) USL Benefit Trust

Assoclate:

i) Wine Society of India Private Limited^

$\wedge$ No transactions during the year

$\wedge \wedge$ Shaw Wallace Breweries Limited renamed as" SW Finance Co. Limited"with effect from 16 January 2013

$\wedge \wedge \wedge$ Whyte and Mackay Singapore Pte Limited renamed as "United Spirits Singapore Pte Limited"with effect from 1 August 2014

Key Management Personnel:

I) Mr Ashok Capoor - Managing Director (effective upto 30 April 2014)

II) Mr P A Murall - Executive Director and CFO (effective upto 22 April 2015)

III) Mr Anand Kripalu - Managing Director and Chief Executive Officer (with effect from 14 August 2014)

Employees' Benefit Plans where there is significant Influence:

I) MCDowell \& Company Limited Staff Gratuity Fund (MCD SGF), II) MCDowell \& Company Limited Officers' Gratuity Fund (MCD OGF), III) Phipson \& Company Limited Management Staff Gratuity Fund (PCL SGF), Iv) Phipson \& Company Limited Gratuity Fund (PCL GF), v) Carew \& Company Ltd. Gratuity Fund (CCL GF), vi) MCDowell \& Company Limited Provident Fund (MCD PF), vil) Shaw Wallace \& Associated Companies Employees Gratuity Fund (SWCEGF), viil) Shaw Wallace \& Assoclated Companles Executive Staff Fund (SWCSGF), Ix) Shaw Wallace \& Co. Associated Companies Provident Fund (SWCPF), x) Balaji Distilleries Employees Gratuity Trust

(b) Summary of the transactions with related parties:

\begin{tabular}{|c|c|c|c|c|c|c|c|c|c|c|c|}
\hline \multirow{2}{*}{$\begin{array}{c}\text { Sl. } \\
\text { No. }\end{array}$} & \multirow[t]{2}{*}{ Nature of transactions * } & \multicolumn{5}{|c|}{ March 2015} & \multicolumn{5}{|c|}{ March 2014} \\
\hline & & \begin{tabular}{c|} 
Entities \\
where there \\
is control
\end{tabular} & $\begin{array}{c}\text { Key } \\
\text { management } \\
\text { personnel }\end{array}$ & \begin{tabular}{|c|} 
Employees' \\
benefit plans \\
where there \\
is significant \\
influence
\end{tabular} & \begin{tabular}{|c|} 
Holding \\
company/ \\
Fellow \\
subsidiaries/ \\
Entities having \\
significant \\
influence/ \\
Entities under \\
common \\
influence or \\
control
\end{tabular} & Total & $\begin{array}{c}\text { Entities } \\
\text { where there } \\
\text { is control }\end{array}$ & $\begin{array}{c}\text { Key } \\
\text { management } \\
\text { personnel }\end{array}$ & $\begin{array}{l}\text { Employees' } \\
\text { benefit plans } \\
\text { where there } \\
\text { is significant } \\
\text { influence }\end{array}$ & $\begin{array}{l}\text { Holding } \\
\text { company/ } \\
\text { Fellow } \\
\text { subsidiaries/ } \\
\text { Entities having } \\
\text { significant } \\
\text { influence/ } \\
\text { Entities under } \\
\text { common } \\
\text { influence or } \\
\text { control }\end{array}$ & Total \\
\hline \multirow[t]{9}{*}{ a) } & Purchase of goods & & & & & & & & & & \\
\hline & -Whyte \& Mackay Limited $\boldsymbol{*}$ & $1,046,031$ & - & - & - & $1,046.031$ & $2,397.560$ & - & - & - & $2,397.560$ \\
\hline & - Tern Distilleries Private Limited & 195628 & - & - & - & 195.628 & 121.905 & - & - & - & 121.905 \\
\hline & - Proneer Distilleries Limited & $1,350.433$ & - & - & - & $1,350.433$ & 851.303 & - & - & - & 851.303 \\
\hline & - Sovereign Distilleries Limitec & - & - & - & - & - & 0.033 & - & - & - & 0.033 \\
\hline & - Four Seasors Wines Limited & 94.254 & - & - & - & 94.254 & 110.443 & - & - & - & 110.443 \\
\hline & - Bouvet Ladubay S.AS. & 0321 & - & - & - & 0.321 & 0.738 & - & - & - & 0.738 \\
\hline & - Diageo Brands BV & - & - & - & 255.863 & 255.863 & - & - & - & - & - \\
\hline & - Diageo Scotland Limited & - & - & - & - & - & - & - & - & 702.849 & 702849 \\
\hline
\end{tabular}




\section{Notes to the financial statements (continued)}

24. Related party disclosures (contd...)

(b) Summary of the transactions with related parties:

\begin{tabular}{|c|c|c|c|c|c|c|c|c|c|c|c|}
\hline \multirow{2}{*}{$\begin{array}{l}\text { SI. } \\
\text { No. }\end{array}$} & \multirow{2}{*}{ Nature of transactions * } & \multicolumn{5}{|c|}{ March 2015} & \multicolumn{5}{|c|}{ March 2014} \\
\hline & & $\begin{array}{c}\text { Entities } \\
\text { where there } \\
\text { is control }\end{array}$ & $\begin{array}{c}\text { Key } \\
\text { management } \\
\text { personnel }\end{array}$ & $\begin{array}{l}\text { Employees' } \\
\text { benefit plans } \\
\text { where there } \\
\text { is significant } \\
\text { influence }\end{array}$ & $\begin{array}{l}\text { Holding } \\
\text { company/ } \\
\text { Fellow } \\
\text { subsidiaries/ } \\
\text { Entities having } \\
\text { significant } \\
\text { influence/ } \\
\text { Entities under } \\
\text { common } \\
\text { influence or } \\
\text { control }\end{array}$ & Total & $\begin{array}{c}\text { Entities } \\
\text { where there } \\
\text { is control }\end{array}$ & $\begin{array}{c}\text { Key } \\
\text { management } \\
\text { personnel }\end{array}$ & $\begin{array}{l}\text { Employees' } \\
\text { benefit plans } \\
\text { where there } \\
\text { is significant } \\
\text { influence }\end{array}$ & $\begin{array}{l}\text { Holding } \\
\text { company/ } \\
\text { Fellow } \\
\text { subsidiaries/ } \\
\text { Entities having } \\
\text { significant } \\
\text { influence/ } \\
\text { Entities under } \\
\text { common } \\
\text { influence or } \\
\text { contro }\end{array}$ & Total \\
\hline \multirow[t]{5}{*}{ b) } & Sale of goods & & & & & & & & & & \\
\hline & - United Spirits Nepal Private Limited & 145.173 & - & - & - & 145.173 & 174.435 & - & - & - & 174.435 \\
\hline & - United Breveries (Holdings) Limitec & - & - & - & 50.833 & 50.833 & - & - & - & 507.649 & 507.649 \\
\hline & - Pioneer Distilleries Limited & 3.150 & - & - & - & 3.150 & - & - & - & - & - \\
\hline & - United Spirits Singapore Pte Limited & $1,206.900$ & - & - & - & 1.206 .980 & $974.22 \varepsilon$ & - & - & - & 974.228 \\
\hline \multirow[t]{3}{*}{ c) } & Income from brand franchise & & & & & & & & & & \\
\hline & - United Spirits Nepal Private Limited & 53.460 & - & - & - & 53.460 & 58.091 & - & - & - & 58.091 \\
\hline & $\begin{array}{l}\text { - Royal Challergers Sports Private } \\
\text { Limitec }\end{array}$ & - & - & - & - & - & 5.000 & - & - & - & 5.000 \\
\hline \multirow[t]{2}{*}{ d) } & Income from agency commission & & & & & & & & & & \\
\hline & - Diageo India Private Limited & - & - & - & 369.191 & 369.191 & - & - & - & 164.008 & 164.008 \\
\hline \multirow[t]{4}{*}{ e] } & Otheroperating income & & & & & & & & & & \\
\hline & - United Spirits Singapore Pte Limited & 189.408 & - & - & - & 189.408 & 142.814 & - & - & - & 142814 \\
\hline & - Pioneer Distilleries Limited & 0.019 & - & - & - & 0.019 & - & - & - & - & - \\
\hline & - Whyte \& Mackay Limited * & 0.491 & - & - & - & 0.491 & - & - & - & - & - \\
\hline \multirow[t]{2}{*}{ f) } & Dividend received & & & & & & & & & & \\
\hline & - United Spirits Nepal Private Limited & 14.813 & - & - & - & 14813 & 23.277 & - & - & - & 23.277 \\
\hline \multirow[t]{10}{*}{ g) } & Interest income & & & & & & & & & & \\
\hline & - SW Finance Ca Limited & - & - & - & - & - & $70.46 \varepsilon$ & - & - & - & 70.468 \\
\hline & $\begin{array}{l}\text { - Asian Opportunities \& Investments } \\
\text { Limited }\end{array}$ & 2.292 & - & - & - & 2.292 & - & - & - & - & - \\
\hline & - USL Holdings Limited & 100.550 & - & - & - & 100.550 & - & - & - & - & - \\
\hline & - Pioneer Distilleries Limited & 305.772 & - & - & - & 305.772 & 85.924 & - & - & - & 85.924 \\
\hline & - Four Seasons Wines Limited & 46.282 & - & - & - & 46.282 & 29.378 & - & - & - & 29.378 \\
\hline & $\begin{array}{l}\text { - United Breweries (Holdings) } \\
\text { Limited ^ }\end{array}$ & - & - & - & 63.527 & 63.527 & - & - & - & 107.006 & 107.006 \\
\hline & $\begin{array}{l}\text { - Royal Challengers Sports Private } \\
\text { Limited }\end{array}$ & 221.332 & - & - & - & 221.332 & 126.697 & - & - & - & 126.697 \\
\hline & - TernDistilleriesPrivate Limitec & 94.875 & - & - & - & 94.875 & $64.69 \varepsilon$ & - & - & - & 64.698 \\
\hline & - Sover eign Distilleries Limited & 371.528 & - & - & - & 371.528 & 244.463 & - & - & - & 244.463 \\
\hline \multirow[t]{2}{*}{ h) } & Interest expenses & & & & & & & & & & \\
\hline & - SW Finance Co. Limited & - & - & - & - & - & 450.155 & - & - & - & 450.155 \\
\hline \multirow[t]{2}{*}{ i) } & Interest payment & & & & & & & & & & \\
\hline & - SW Finance Ca Limited & 75.600 & - & - & - & 75.600 & - & - & - & - & - \\
\hline \multirow[t]{3}{*}{ j) } & Guarantee commission-received & & & & & & & & & & \\
\hline & - USL Holdings Limited & - & - & - & - & - & 37.184 & - & - & - & 37.184 \\
\hline & - USL Hbldings (UK) Limited & - & - & - & - & - & 186.559 & - & - & - & 186.559 \\
\hline \multirow[t]{3}{*}{ k) } & $\begin{array}{l}\text { Advertisement \& sales promotion } \\
\text { expenses }\end{array}$ & & & & & & & & & & \\
\hline & - United Breweries (Holdings) Limitec & - & - & - & - & - & - & - & - & 63.908 & 63.908 \\
\hline & - Whyte \& Mackay Limited * & - & - & - & - & - & 10.775 & - & - & - & 10.775 \\
\hline \multirow[t]{3}{*}{ l) } & Rent & & & & & & & & & & \\
\hline & - Whyte \& Mackay Limi ted * & 89.648 & - & - & - & 89.648 & 130.767 & - & - & - & 130.767 \\
\hline & - McDowell \& Co (Scotland) Limitec & 7.196 & - & - & - & 7.196 & 14.818 & - & - & - & 14.818 \\
\hline \multirow[t]{2}{*}{ m) } & Blending and sampling charges & & & & & & & & & & \\
\hline & - Whyte \& Mackay Limited * & 1.894 & - & - & - & 1.894 & - & - & - & - & - \\
\hline \multirow[t]{2}{*}{ n) } & Wood repair charges & & & & & & & & & & \\
\hline & - Whyte \& Mackay Limi ted "* & 1.475 & - & - & - & 1.475 & - & - & - & - & 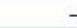 \\
\hline
\end{tabular}




\section{Notes to the financial statements (continued)}

24. Related party disclosures (contd...)

(b) Summary of the transactions with related partles (Continued):

\begin{tabular}{|c|c|c|c|c|c|c|c|c|c|c|c|}
\hline \multirow{2}{*}{$\begin{array}{l}\text { SI. } \\
\text { No. }\end{array}$} & \multirow[t]{2}{*}{ Nature of transactions * } & \multicolumn{5}{|c|}{ March 2015} & \multicolumn{5}{|c|}{ March 2014} \\
\hline & & $\begin{array}{l}\text { Entities } \\
\text { where } \\
\text { there is } \\
\text { control }\end{array}$ & \begin{tabular}{|c|} 
Key \\
management \\
personnel
\end{tabular} & $\begin{array}{c}\text { Employees' } \\
\text { benefit } \\
\text { plans where } \\
\text { there is } \\
\text { significant } \\
\text { influence }\end{array}$ & \begin{tabular}{|c|} 
Holding \\
company' \\
Fellow \\
subsidiaries/ \\
Entities having \\
significant \\
influence' \\
Entities under \\
cornmon \\
influence or \\
control
\end{tabular} & Total & $\begin{array}{l}\text { Entities } \\
\text { where } \\
\text { there is } \\
\text { control }\end{array}$ & $\begin{array}{c}\text { Key } \\
\text { management } \\
\text { personnel }\end{array}$ & $\begin{array}{l}\text { Employees' } \\
\text { benefit plans } \\
\text { where there } \\
\text { is significant } \\
\text { influence }\end{array}$ & $\begin{array}{l}\text { Holding } \\
\text { company' } \\
\text { Fellow } \\
\text { subsidiaries/ } \\
\text { Entities having } \\
\text { significant } \\
\text { influence/ } \\
\text { Entities under } \\
\text { common } \\
\text { influence or } \\
\text { control }\end{array}$ & Total \\
\hline \multirow[t]{2}{*}{ o) } & Salary recharge & & & & & & & & & & \\
\hline & - Diageo India Private Limited & - & - & - & 61.491 & 61.491 & - & - & - & 167887 & 167887 \\
\hline \multirow[t]{2}{*}{ p) } & Trade mark license fee & & & & & & & & & & \\
\hline & - United Breweries (Holdings) Limited & - & - & - & 576.407 & 576407 & - & - & - & 432.743 & 432.743 \\
\hline \multirow[t]{2}{*}{ q) } & Property maintenance fees & & & & & & & & & & \\
\hline & - Kingfisher Firwest India Limited & - & - & - & 127.341 & 127.341 & - & - & - & 143.259 & 143.259 \\
\hline \multirow[t]{2}{*}{ r) } & Guarantee / security com mis sion paid & & & & & & & & - & & \\
\hline & - United Breweries(Holdings) Limited & - & - & - & 7.831 & 7.831 & - & - & - & 5.500 & 5.500 \\
\hline \multirow[t]{4}{*}{ s) } & Sale/ (purchase) of fixed asset & & & & & & & & & & \\
\hline & - Whyte \& Mackay Limited $\boldsymbol{H}$ & (3.444; & - & - & - & (3.444) & (290.384) & - & - & - & (290.384) \\
\hline & - Tern Distilleries Private Limited & - & - & - & - & - & 0.120 & - & - & - & 0.120 \\
\hline & - Pioneer Distilleries Limited & 3.640 & - & - & - & 3.640 & 4.182 & - & - & - & 4.182 \\
\hline \multirow[t]{10}{*}{ t) } & $\begin{array}{l}\text { Finance (including loans and advances, } \\
\text { equity contributions in cash or in kind) }\end{array}$ & & & & & & & & & & \\
\hline & - USL HoldingsLimitec & 20.165 & - & - & - & 20.165 & 2111.145 & - & - & - & 2.111 .145 \\
\hline & - Royal Challengers Sports Private Limitec & 755.700 & - & - & - & 755.700 & 766.879 & - & - & - & 766879 \\
\hline & - Asian Opportunities \& Investments Limitec & 75.700 & - & - & - & 75.700 & - & - & - & - & - \\
\hline & - Four Sea sors Wines Limited & 15.115 & - & - & - & 15.115 & 60.550 & - & - & - & 60.550 \\
\hline & -SW Finance Co. Limited & - & - & - & - & - & 119.796 & - & - & - & 119.796 \\
\hline & - Sovereign Distilleries Limited & 670.203 & - & - & - & 670.203 & $1,522.944$ & - & - & - & $1,522.944$ \\
\hline & - Pioneer Distilleries Limited & - & - & - & - & - & 249.726 & - & - & - & 249.726 \\
\hline & - United Breweries (Holdings) Limited & - & - & - & - & - & - & - & - & $8,391.816$ & $8,391.816$ \\
\hline & - Tern Distilleries Private Limited & 172.525 & - & - & - & 172.525 & 157.777 & - & - & - & 157.777 \\
\hline \multirow[t]{4}{*}{ u) } & Remuneration & & & & & & & & & & \\
\hline & - Managing Director (AshokCapoor) & - & 2894 & - & - & 2894 & - & 66.169 & - & - & 66.169 \\
\hline & - Managing Director (Anand Kripalu) & - & 62013 & - & - & 62013 & - & - & - & - & - \\
\hline & - Executive Director (P A Murali) & - & 153.092 & - & - & 153.092 & - & 47.792 & - & - & 47.792 \\
\hline \multirow[t]{3}{*}{ v) } & Rent & & & & & & & & & & \\
\hline & - Managing Director (AshokCapoor', & - & 0.720 & - & - & 0.720 & - & 8.290 & - & - & 8.290 \\
\hline & - Executive Director (P A Murali) & - & 14.454 & - & - & 14.454 & - & 7.938 & - & - & 7.938 \\
\hline \multirow[t]{3}{*}{ w) } & Contribution to gratuity fund & & & & & & & & & & \\
\hline & $\begin{array}{l}\text { - MEDowell \& Company Limited Officers' } \\
\text { Gratuity Fund }\end{array}$ & - & - & 332283 & - & 332283 & - & - & 193.010 & - & 193.010 \\
\hline & $\begin{array}{l}\text { - Mc Dowell \& Company Limited Staff } \\
\text { Gratuity fund }\end{array}$ & - & - & 180.920 & - & 180.920 & - & - & 54.681 & - & 54.681 \\
\hline \multirow[t]{2}{*}{$\mathrm{x})$} & Contribution to provident fund & & & & & & & & & & \\
\hline & $\begin{array}{l}\text { - McD owell \& Compary Limited Provident } \\
\text { Func }\end{array}$ & - & - & 359.462 & - & 359.462 & - & - & 134.583 & - & 134.583 \\
\hline \multirow[t]{4}{*}{ y) } & Dividend paid & & & & & & & & & & \\
\hline & - USL Benefit Trust & - & - & - & - & - & 8.648 & - & - & - & 8.648 \\
\hline & - United Breweries(Holdings) Limited & - & - & - & - & - & - & - & - & 25.369 & 25.369 \\
\hline & - Relay BV & - & - & - & - & - & - & - & - & 90.898 & 90898 \\
\hline \multirow[t]{4}{*}{ z) } & $\begin{array}{l}\text { Guarantees and collaterak given / } \\
\text { (withdrawn) }\end{array}$ & & & & & & & & & & \\
\hline & - USLHoldings Limitec & $\left(1,244.880^{\prime}\right.$ & - & - & - & $(1,244.880)$ & $(7.954 .350)$ & - & - & - & $(7,954.350)$ \\
\hline & - USL Holdings (UK) Limitec & - & - & - & - & & $(40,300.000)$ & - & - & - & $(40,300.000)$ \\
\hline & - Sovereign Distilleries Limitec & - & - & - & - & - & $(1,250.000)$ & - & - & - & $(1,250.000)$ \\
\hline \multirow[t]{2}{*}{ aa) } & Guarantees (received)/ reduced & & & & & & & & & & \\
\hline & - Four Seasors Wines Limited & - & - & - & - & - & $1,500.000$ & - & - & - & $1,500.000$ \\
\hline
\end{tabular}




\section{Notes to the financial statements (continued)}

24. Related party disclosures (contd...)

(b) Summary of the transactions with related parties (Continued):

\begin{tabular}{|c|c|c|c|c|c|c|c|c|c|c|c|}
\hline \multirow{2}{*}{$\begin{array}{l}\text { SI. } \\
\text { No. }\end{array}$} & \multirow[t]{2}{*}{ Nature of trans actions * } & \multicolumn{5}{|c|}{ March 2015} & \multicolumn{5}{|c|}{ March 2014} \\
\hline & & $\begin{array}{c}\text { Entities } \\
\text { where } \\
\text { there is } \\
\text { control }\end{array}$ & $\begin{array}{c}\text { Key } \\
\text { management } \\
\text { personnel }\end{array}$ & $\begin{array}{c}\text { Employees } \\
\text { benefit } \\
\text { planswhere } \\
\text { there is } \\
\text { significant } \\
\text { influence }\end{array}$ & \begin{tabular}{|c|} 
Holding \\
company/ \\
Fellow \\
subsidiaries/ \\
Entities having \\
significant \\
influence/ \\
Entities under \\
common \\
influence or \\
control
\end{tabular} & Total & $\begin{array}{l}\text { Entities } \\
\text { where } \\
\text { there is } \\
\text { control }\end{array}$ & $\begin{array}{c}\text { Key } \\
\text { management } \\
\text { personnel }\end{array}$ & $\begin{array}{l}\text { Employees' } \\
\text { benefit plans } \\
\text { where there } \\
\text { is significant } \\
\text { influence }\end{array}$ & $\begin{array}{l}\text { Holding } \\
\text { company/ } \\
\text { Fellow } \\
\text { subsidiaries/ } \\
\text { Entities having } \\
\text { significant } \\
\text { influence/ } \\
\text { Entities under } \\
\text { common } \\
\text { influence or } \\
\text { contro }\end{array}$ & Total \\
\hline \multirow[t]{8}{*}{ ab: } & Provisions for doubtful loans and advances & & & & & & & & & & \\
\hline & - USL Hbldings Limited & $2,144.468$ & - & - & - & $2,144.468$ & $36,142.314$ & - & - & - & $36,142.314$ \\
\hline & - USL Hbldings (UK) Limited & 178.411 & - & - & - & 178.411 & - & - & - & - & - \\
\hline & - Pioneer Distilleries Limited & 819.020 & - & - & - & 819.020 & - & - & - & - & - \\
\hline & -Sovereign Distilleries Limited & 2207.090 & - & - & - & 2207.090 & - & - & - & - & - \\
\hline & - Asian Oppor tunities \& Investments Limited & 245.477 & - & - & - & 245.477 & - & - & - & - & - \\
\hline & - Tern Distilleries Private Limitec & 271.910 & - & - & - & 271.910 & - & - & - & - & - \\
\hline & $\begin{array}{l}\text { - United Breveries (Holdings) Limited } \\
\text { (Includes provision for interest ₹ Nil (2014: } \\
\text { ₹ } 963.069 \text { Million) }\end{array}$ & - & - & - & $9,954.596$ & $9,954.596$ & - & - & - & $4,266.255$ & $4,266.255$ \\
\hline \multirow[t]{2}{*}{ ac) } & $\begin{array}{l}\text { Expenses incurred on behalf of the } \\
\text { Company, reimbursable }\end{array}$ & & & & & & & & & & \\
\hline & - United Breveries Limitec & - & - & - & 4.791 & 4.791 & - & - & - & 6.483 & 6.483 \\
\hline \multirow[t]{2}{*}{ ad] } & $\begin{array}{l}\text { Expenses incurred by the Company on } \\
\text { behalf of others, reimburs able }\end{array}$ & & & & & & & & & & \\
\hline & - United Brewe ries Limitec & - & - & - & 12.037 & 12.037 & - & - & - & 17.120 & 17.120 \\
\hline \multirow[t]{2}{*}{ ae) } & $\begin{array}{l}\text { Housekeeping ,Security and other } \\
\text { Maintenance Services }\end{array}$ & & & & & & & & & & \\
\hline & $\begin{array}{l}\text { - City Properties Maintenance Company } \\
\text { Bangalore Limi ted }\end{array}$ & - & - & - & 50.559 & 50.559 & - & - & - & 40.748 & 40.748 \\
\hline
\end{tabular}

